\title{
New genera and species of gall midges (Diptera, Cecidomyiidae) from three restingas of Rio de Janeiro State, Brazil
}

\section{Valéria Cid Maia $^{1}$}

\begin{abstract}
Five new genera and fourteen new species of gall midges from restingas of Rio de Janeiro State are described. The larva, pupa, male, female and gall are described for each species. The new genera are: Arrabidaeamyia, Epihormomyia, Manilkaramyia, Mayteniella and Parazalepidota. The new species are: Arrabidaeamyia serrata, Asphondylia peploniae, Clinodiplosis diodiae, Clinodiplosis profusa, Clusiamyia granulosa, Dasineura couepiae, Epihormomyia miconiae, Lopesia grandis, Lopesia marginalis, Lopesia singularis, Manilkaramyia notabilis, Mayteniella distincta, Parazalepidota clusiae and Paulliniamyia ampla. Also, the larva of a previously described species, Clusiamyia nitida Maia, 1996 is described and Asphondylia byrsonimae Maia \& Couri is transferred to Bruggmaniella.

KEY WORDS. Gall, Cecidomyiidae, restinga, taxonomy
\end{abstract}

The Cecidomyiidae of Brazil are extremely rich in species although very poorly known. A review of the gall midge fauna of the Neotropical Region was recently made by GAGNÉ (1994), who wrote that the number of gall midges that must occur in the region is inestimable.

This work is a report of new taxa found during a study of the restinga of southeastern Brazil. The ecology and taxonomy of gall midges of this area have been studied by Brazilian researchers for 15 years (COURI \& MAIA 1992; MAIA 1993a, b, c, 1994, 1995a, b, c, 1996a, b; MAIA 1999a, b, c; MAIA \& COURI 1993; MAIA et al. 1992; MONTEIRO et al. 1993; MAIA \& MONTEIRO 1999).

MAIA (in press) described galls and damage produced by Cecidomyiidae from three restingas of Rio de Janeiro State. The new taxa and other taxonomic considerations are treated in this paper. These include five new genera and 14 new species, one new combination, and the description for the first time of the larva of Clusiamyia nitida Maia, 1996. They are presented in alphabetical order.

\section{MATERIAL AND METHODS}

The specimens studied in this work were collected in three restingas of Rio de Janeiro State (Barra de Maricá, Itaipuaçu and Carapebus). The restinga of Barra de Maricá were investigated from 1985 until 1999, those of Itaipuaçu and Carapebus from 1997 until 1998 and from 1998 until 1999, respectively. The specimens were obtained by rearing following the methods of MAIA (in press). The immature stages (larva of third instar and pupa or pupal exuviae) and adults (male and female) were prepared and mounted on slides following the methods of GAGNÉ (1994). Additional

1) Departamento de Entomologia, Museu Nacional. Quinta da Boa Vista, São Cristóvão, 20940-040 Rio de Janeiro, Rio de Janeiro. E-mail: maiavcid@acd.ufrj.br 
material of the gall maker associated with Clusia fluminensis Tr. \& Pl. (Clusiaceae) were collected in Niterói (Rio de Janeiro State). All specimens (including the types) were incorporated in the Diptera collection of Museu Nacional, Rio de Janeiro. The terminology of the adult stage follows MCALPINE et al. (1981) and that of the immature stages follows GAGNÉ (1989).

\section{Arrabiadaeamyia gen. $\mathbf{n}$.}

Larva. Cylindrical shaped and regular in width. Spatula with four developed teeth. Full complement of lateral papillae; sternal papillae nonsetose.

Pupa. Full complement of cephalic, lower and lateral papillae. Antennal horn well developed and with serrated margin.

Adult. Head: Occipital process absent; palpus 4-segmented; basal flagellomeres longer than distal ones; male: binodal and tricircumfilar flagellomeres; female: circumfila as two undulate horizontal rings. Flagellomere 12 with apical process.

Thorax. Wing: R5 longer than wing, joining $\mathrm{C}$ beyond wing apex; Rs partially as strong as R1, but weak anteriorly; base of $\mathrm{M}$ curve; CuP absent. First tarsomeres without spur; fifth tarsomere appreciably longer than first; tarsal claws simple and bent beyond its midlength; empodia short, not reaching tarsal curvature.

Abdomen. Gonocoxite with mesobasal lobes well developed. Ovipositor short, barely protrusible; female cerci separate and with setae evenly distributed.

Remarks. This genus is included among the Cecidomyiidi due to the number and shape of the flagellomeres but does not fit in any known tribe. It will key to Styracodiplosis Tavares, 1915 in couplet 87 of GAGNÉ (1994), if one ignores the host plant, but Styracodiplosis has bilobed hypoproct and gonocoxite lacks well developed mesobasal lobes, whereas Arrabiadaeamyia gen. n. has a simple hypoproct and mesobasal gonocoxite lobes.

Type species: Arrabiadaeamyia serrata $\mathbf{s p .} \mathbf{n}$.

Etymology. The generic name is composed of Arrabiadaea (the generic name of the host plant species) + myia.

\section{Arrabiadaeamyia serrata sp. $\mathrm{n}$.}

Figs 1-7

Larva. Body length: 2.2-3.3 mm. Color: yellow. Spatula (length: 0.18-0.31 $\mathrm{mm}$; 4-toothed (inner teeth longer than outer ones) (Fig. 1); full complement of lateral papillae (Fig. 1). Terminal segment rounded and with two pairs of setose papillae.

Pupa. Body length: 2.7-3.3 mm. Cephalic region (Fig. 2): antennal horn with 0.14-0.17 mm of length; cephalic seta with 0.07-0.09 mm of length; full complement of lower and lateral facial papillae. Prothoracic spiracle setiform (length: 0.23-0.25 $\mathrm{mm}$ ). Wing sheath reaching the mid limit of the abdominal segment 3 . Fore, mid and hind legs sheath reaching the distal margin of the abdominal segment 5 , distal margin of basal $1 / 5$ of the abdominal segment 6 and midlength of this same segment, respectively. Abdominal tergites 2-8 with numerous and very short spinules, all of the same size. 


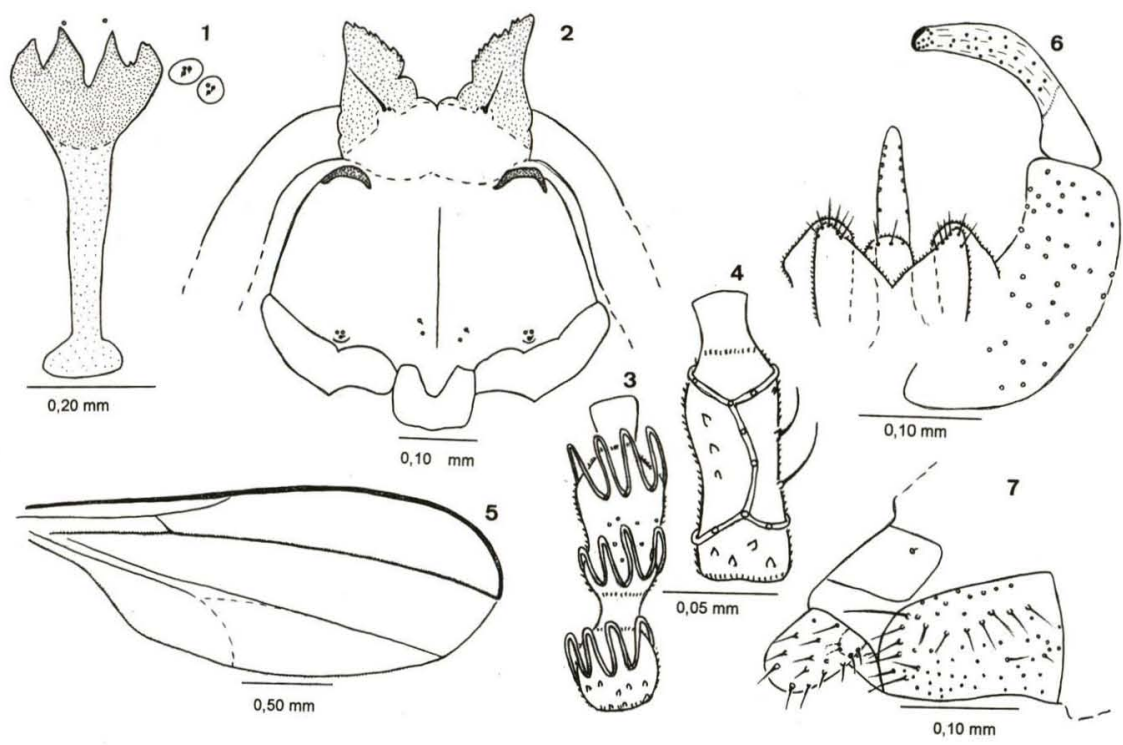

Figs 1-7. Arrabiadaeamyia serrata sp. n. (1) Larva, spatula, sternal and lateral papillae (ventral); (2) pupa, cephalic region (ventral); (3) male, flagellomere $\mathrm{V}$; (4) female, flagellomere

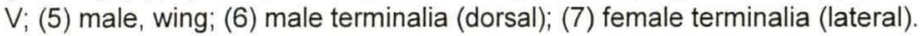

Adult. Head: Eyes facets hexagonal. Flagellomeres binodal and tricircumfilar in male, loops of similar length (Fig. 3). Two undulate horizontal rings in female (Fig. 4). Flagellomeres neck bare. Frontoclypeus with few long setae. Labrum triangular, long-attenuate, with 4-6 pairs of ventral sensory setae and long, anteriorly directed lateral setulae. Hypopharynx longer than labrum with long, anteriorly directed, lateral setulae. Labella elongate-convex, each with several long lateral setae and two short mesal sensory setae. Palpus with four segments, each long, setose and progressively longer.

Thorax. Wings (Fig. 5): length: 2.5-2.8 mm. Anepisternum with a few scales near middle. Anepimeron with vertical row of several setae. Tarsal claws bent beyond its midlength, simple on all legs. Empodia rudimentary.

Abdomen. Tergites 1-7 rectangular with 2-3 irregular rows of setae at distal margin. Tergite 8 (male): quadrangular with two trichoid sensilla. Sternites 1-5 rectangular with one row of setae at distal margin and setae evenly distributed. Sternite 6 rectangular with setae evenly distributed, more abundant at distal margin. Sternite 7 ovoid and setose. Male terminalia (Fig. 6): gonocoxite not splayed, gonostylus strongly bent near its midlength; cercus triangular; hypoproct simple and rounded at the apex; gonocoxite with lobes mesobasal well developed; aedegus elongated with pointed apex. Ovipositor barely protrusible, female cerci ovoid and setose (2 setae longer than the others) (Fig. 7).

Material. Holotype male. BRAZIL, Rio de Janeiro: Maricá, 05.VI.1998, V. Maia leg., MNRJ. Paratypes: same locality and collector - 1 male, 05.VI.1998; 3 
males, 05.VI.1998 (emerg.: 23.VI.1998); 1 male, 25.IV.1998; 1 female VIII.1998; 1 female, II.1998; 5 pupal exuviae, 05.VII.1998; 2 larvae, 10.X.1997; 3 larvae, 06.XII.1997; 1 larva, 21.III.1999, MNRJ.

Gall. Conical leaf gall (length: $0.8-1.4 \mathrm{~cm}$; basal width: $0.5 \mathrm{~cm}$ ), glabrous, monothalamous, green. Host Plant: Arrabidaea conjugata (Vell.) Mart. (Bignoniaceae).

Etymology. The name serrata refers to the serrate pupa antennal horn.

\section{Asphondylia peploniae sp. $\mathbf{n}$.}

Figs 8-14

Larva. Body length: 2.4-3.1 mm. Color: white. General aspect: body wide anteriorly and gradually tapering to the posterior end. Terminal segment reduced. Spatula (Fig. 8) clove-shaped with $0.2 \mathrm{~mm}$ of length, stalk with $0.07-0.09 \mathrm{~mm}$ of length; three pairs of setose lateral papillae. Terminal segment with two corniform papillae.

Pupa. Body length: 3.51-4.80 mm. Cephalic region (Fig. 9): antennal horn rectangular (length: $0.15-0.20 \mathrm{~mm}$ ); cervical sclerite with two pairs of papillae (one setose and one without seta), cervical seta with $0.02-0.03 \mathrm{~mm}$ of length; upper margin of cephalic region thickened laterally; upper frontal horn short, wide with simple apex; lower frontal horn elongate and simple; two pairs of lower facial papillae (one setose and one without seta), three pairs of lateral papillae (2 with seta and one bare). Prothoracic spiracle setiform, relatively short (length: $0.14-0.20 \mathrm{~mm}$ ). Fore, mid and hind leg sheaths subequal in length, reaching the basal margin of the abdominal segment 5 . Abdominal tergites $2-8$ with spines progressively longer and closer to each from anterior to posterior margin, irregularly distributed in the basal half of each tergite, forming a row of well-developed spines at distal $3 / 4$ and absent in the distal 1/4 (Fig. 10).

Adult. Head: Eye facets hexagonal, closely approximated. Antennae with scape 1.75 times longer than pedicel; pedicel about as wide as long; first flagellomere about 1.7 times longer than scape; proportions of female segments and flagellomeres as in figure 11; last flagellomere globular in female and cylindrical in male; male circumfila sinuous (Fig. 12); female circumfila as in figure 13. Frons with 24-25 setae. Clypeus asetose dorsally, with short setae laterally, and setulose ventrally. Hypopharynx closely lined with setulae dorsoapically. Labella setose and setulose laterally and ventrally (with small area of setulae and 0-1 setae mesally). Palpus three segmented, first segment about as long as wide (length: 0.02-0.03 mm), second segment about three times as long as wide; second and third segment with 0.07-0.08 $\mathrm{mm}$ of length, third narrower than the second, about five times as long as wide, all covered with setulae and setae.

Thorax. Wings length, male, 2.2-2.4 $(n=4)$, female, 2.7-2.8 $(n=4)$. Dorsal setal row at midlength with two/three rows of setae intermixed with (several) scales, the row continuing onto scutellum to posterior margin. Scutellum bare between dorsocentral rows of setae, with setae posteriorly laterad of dorsocentral rows, and otherwise with sparse scales laterally. Anepisternum with setae and scales on dorsal 


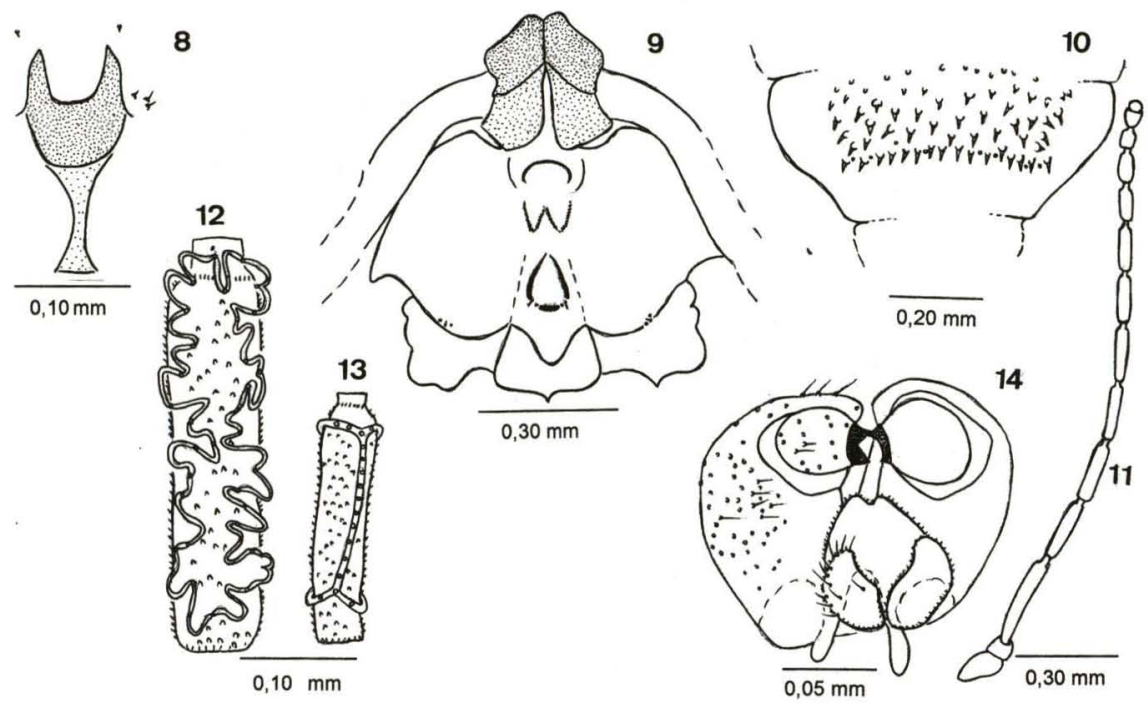

Figs 8-14. Asphondylia peploniae sp. n. (8) larva, spatula, sternal and lateral papillae (ventral); (9) pupa, cephalic region (ventral); (10) pupa, abdominal segment VII (dorsal); (11) female, antenna; (12) male, flagellomere $\mathrm{V} ;(13)$ female, flagellomere $\mathrm{V} ;(14)$ male terminalia (dorsal).

half. Anepimeron covered with setae. Katepimeron bare. Tarsal claws all equal in size and shape, as long as empodia. First tarsomeres with a spur $0.05 \mathrm{~mm}$ of length.

Abdomen. Tergites without anterior pair of trichoid sensilla, first through seventh tergites rectangular with mostly double row of posterior setae (sparser in male than in female), several lateral setae, elsewhere covered with scales, width of sixth and seventh tergites about three times length; eigth tergite short, bandlike, without vestiture. Sternites without anterior pair of trichoid sensilla, width sixth sternite about twice length, male eigth sternite reduced in size, as wide as long. Male terminalia (Fig. 14): gonocoxite wide; gonostylus rounded; cercus constricted near midlength; hypoproct slightly bilobed; aedegus elongate, tapering to apex. Ovipositor 1.8-1.9 times as long as seventh sternite.

Material. Holotype male. BRAzIL, Rio de Janeiro: Carapebus, 29.VIII.1998, V. Maia leg., MNRJ. Paratypes: same locality and collector-2 males, 25.VII.1998; 1 male, 29.VIII.1998; 1 female, 29.VII.1998 (emerg.: 29.VII.1998); 2 females, 29.VII.1998 (emerg.: 30.VII.1998); 1 female, 29.VII.1998; 5 pupal exuviae, 25.VII. 1998; 1 pupal exuviae, 29.VIII.1998; 6 larvae, 29.VIII.1998; 1 larva, 19.XII.1998, MNRJ.

Gall. Closed flower (length: $0.6 \mathrm{~cm}$, medial width: $0.4 \mathrm{~cm}$ ), glabrous, monothalamous and green. Host plant: Peplonia asteria (Vell.) Font. \& Schw. (Asclepiadaceae).

Etymology. The name peploniae is the genitive of the host plant name. 
Remarks. Seven species of Asphondylia Loew, 1850 have been recorded from restingas in Brazil: A. borreriae Rubsaamen, 1905; A. communis Maia \& Couri, 1992; A. cordiae Möhn, 1959; A. maricensis Maia \& Couri, 1992; Asphondylia sp. 1, gall maker on Vernonia rufogrisea St. Hill. (Asteraceae); Asphondylia sp. 2, gall maker on Erythroxylum ovalifolium Peyr. (Erythroxylaceae) and Asphondylia peploniae sp. $\mathbf{n}$.

Asphondylia peploniae sp. $\mathbf{n}$. is easily distinguishable from the other restinga species. The morphological differences are more evident in larva and pupa. The larva of $A$. peploniae has two teeth, as in A. maricensis, but they are conspicuously more splayed in the former. Asphondylia cordiae, A. maricensis and Asphondylia sp. 2 have four teeth on the larval spatula. Those of A. commnunis and Asphondylia sp. 1 are unknown. The pupa of $A$. peploniae is remarkable for the shape of the cephalic horns. The upper frontal horns are simple in A. peploniae, A. borreriae and Asphondylia sp. 2, but they are appreciably wider in the former and not tapered to a rounded apex as in the other restinga species. They are bifid only in A. communis. The lower frontal horns are simple and rounded only in A. peploniae. They are trifid in Asphondylia sp. 2, bifid in A. borreriae and simple in A. communis, but triangular. The antennal horns are triangular in A. communis, rounded in A. borreriae and rectangular in A. peploniae and Asphondylia sp. 2, but longer and wider in the new species. The abdominal tergites 2-7 of $A$. peploniae have four rows of stout spines and smaller ones toward the anterior margin of sclerites. This arrangement is also found in A. communis, but the dorsal spines are more concentrated in the former. In A. borreriae and Asphondylia sp. 2 the abdominal tergites 2-7 have only two rows of stout spines. The pupae of $A$. cordiae, A. maricensis and Asphondylia sp. 1 are unknown. Asphondylia peploniae sp. n., A. borreriae, A. communis, A. cordiae and Asphondylia sp. 1 and Asphondylia sp. 2 differ slightly in proportion ovipositor length/sternite 7 length. A. maricensis and Ashondylia sennae Maia \& Couri, 1992 have the highest and lowest proportions, respectively.

\section{Bruggmanniella byrsonimae Maia \& Couri, comb. $\mathbf{n}$.} Asphondylia byrsonimae Maia \& Couri 1992.

This species is transferred here to Bruggmanniella because the tooth of its gonostylus is divided mesally and the pupa lacks a frontal horn and greatly enlarged abdominal spines, all characteristics of Bruggmanniella (GAGNÉ 1994).

\section{Clinodiplosis diodiae sp. $\mathbf{n}$.}

Figs 15-21

Larva. Body length: 2.3-2.6 mm. Color: yellow. Spatula 2-toothed; length: $0.12-0.15 \mathrm{~mm}$ (Fig. 15). Sternal papillae asetose, two groups of three lateral papillae on each side of spatula (Fig. 15). Terminal papillae as in figure 16.

Pupa. Length: 1.9-2.1 mm. Cephalic region (Fig. 17): antennal horn short with $0.013-0.017 \mathrm{~mm}$ of length; cervical seta long (length: $0.16-0.18 \mathrm{~mm}$ ); full complement of cephalic, lower and lateral papillae; upper cephalic margin thickened laterally. Prothoracic spiracle setiform; length: $0.20-0.39 \mathrm{~mm}$. Fore, mid and hind 


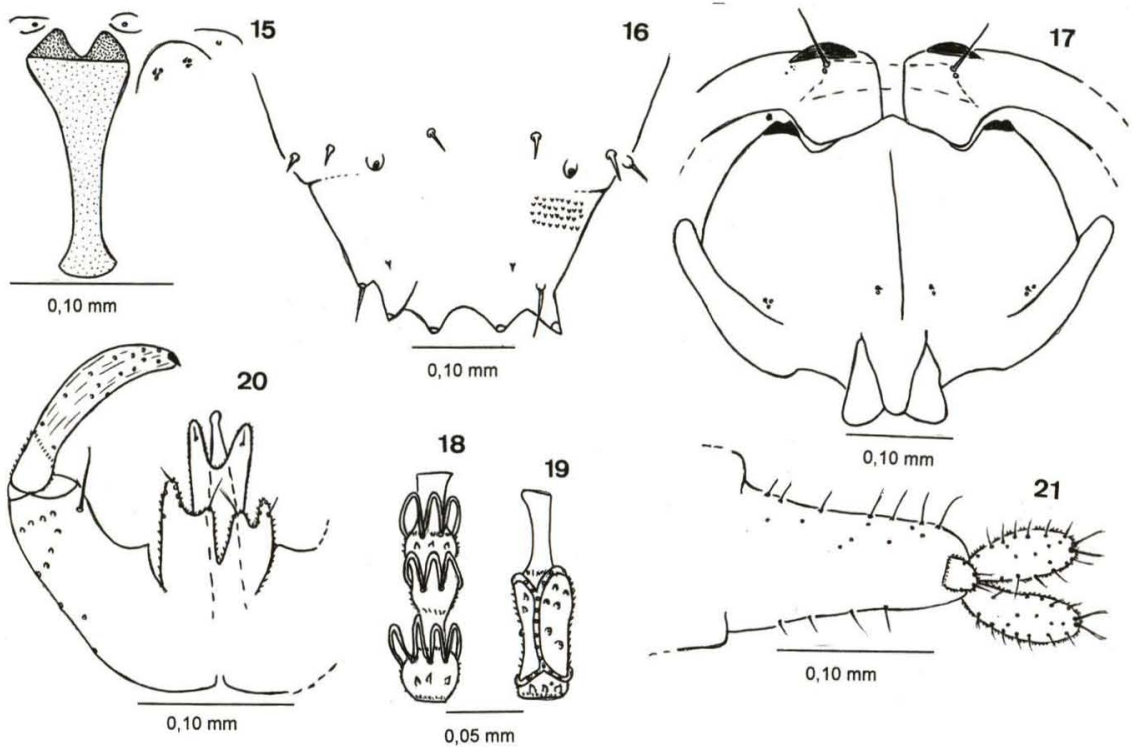

Figs 15-21. Clinodiplosis diodiae sp. n. (15) Larva, spatula, sternal and lateral papillae (ventral); (16) larval posterior segments (dorsal); (17) pupa, cephalic region (ventral); (18) male, flagellomere $\mathrm{V}$; (19) female, flagellomere $\mathrm{V}$ : (20) male terminalia (dorsal); (21) female terminalia (ventral).

leg sheaths subequal in length, reaching basal $1 / 3$ of the abdominal segment 6 . Abdominal tergites II-VIII with abundant dorsal spines, the proximal ones shorter than the distal spines.

Adult. Head: Occipital process present. Eyes facets hexagonal, all closely approximated. Antenna: male flagellomeres (Fig. 18) binodal and tricircumfilar: circumfila loops irregular in length; female flagellomeres cylindrical and circumfila as in figure 19. Flagellomere necks bare; $12^{\text {th }}$ flagellomere with apical process. Frontoclypeus with several long setae. Labrum triangular, long-attenuate, with three pairs of ventral sensory setae and long, anteriorly directed lateral setulae. Hypopharynx of the same shape as labrum with long, anteriorly directed, lateral setulae. Labella elongate-convex, each with several long lateral setae and two short mesal sensory setae. Palpus with four setose, cylindrical and crescent segments, the second the widest one.

Thorax. Wing length: $3.8-4.8 \mathrm{~mm}$. Anepisternum with a few scales near middle. Anepimeron with vertical row of several setae. Tarsal claws thin, bent at basal third and simple on all legs. Empodia reaching to bend in claws.

Abdomen. Tergites 1-7 rectangular with single, complete row of caudal setae, few lateral setae, two basal trichoid sensilla, and elsewhere with scattered scales. Tergite 7 weakly sclerotized caudomesally, caudal setae and scales only 
present laterally; lateral setae and two basal trichoid present. Tergite 8 (male) unsclerotized rectangular with only basal trichoid sensilla for vestiture. Sternites 2-7 rectangular and setose, setae more abundant basally and mesally. Sternite 2-8 quadrate, each with caudal and midlength rows of setae and basal pair of trichoid sensilla. Female: tergites 1-7 as for 1-6 in male, sternites 2-7 as for 2-8 of male, tergite 8 unsclerotized, with a row of short caudal setae and basal pair of trichoid sensilla and short, scattered setae apically. Sternite 9 with scattered setae. Male terminalia (Fig. 20): gonocoxites slightly splayed and narrow distad of mesobasal lobe; gonostylus elongate, narrow, slightly wider at mesal 1/3; gonostylus longer than gonocoxite, slightly wider on distal third at midlength, weakly striated except on basal setulose area; cercus setose and 2-lobed (outer lobe longer than the inner; hypoproct elongate, not broad, deeply concave apically (lobes narrow); parameres absent; aedeagus elongate, tapering gradually to the apex, constricted subapically and sligthly longer than hypoproct. Ovipositor protrusible, female cerci separate, elongate and setose, two setae longer than the others (Fig. 21).

Material. Holotype male. BrazIL, Rio de Janeiro: Carapebus, 31.X.1998 (emerg.: 11.XI.1998), V. Maia leg., MNRJ. Paratype: same locality, date and collector - 1 female (emerg.: 09.XI.1998), 1 pupal exuviae, MNRJ. Paratypes: same locality and collector: 3 males, 28.VIII.1998 (emerg.: 30.VIII.1998), 2 males, 26.IX.1998; 1 male, 28.XI.1998 (emerg.: 29.XI.1998); 1 female, 28.VIII.1998 (emerg.: 04.IX.1998); 1 female, 25.IX.1998 (emerg.: 04.X.1998); 1 female, 26.IX.1998; 6 pupal exuviae, 30.I.1999 (emerg.: 31.I.1998); 5 larvae, 28.VIII.1992, MNRJ.

Gall. Inflorescence gall, fusiform (length: $0.7 \mathrm{~cm}$; basal width: $0.5 \mathrm{~cm}$ ), glabrous, monothalamous and green. Host Plant: Diodia gymnocephala (Rubiaceae).

Etymology. The name diodiae is the genitive of the host plant name.

Remarks. Clinodiplosis diodiae sp. n. differs from the other restinga species, C. profusa sp. n., in having the two apical teeth of the spatula closer, three pairs of corniform terminal papillae and one setiform pair in the terminal segment of the larva, male hypoproct shorter and female cerci wider and shorter. This species is associated with Rubiaceae, whereas the other induces gall on Myrtaceae.

\section{Clinodiplosis profusa sp. $\mathbf{n}$.}

Figs 22-30

Larva. Body length: 3.5-4.0 mm. Color: white. Spatula 2-toothed (teeth stout and not close); length: $0.24-0.26 \mathrm{~mm}$ (Fig. 22). Two pairs of nonsetose lateral papillae on each side (Fig. 22). Four pairs of setose terminal papillae, not equal in length (2 longer than the others) (Fig. 23).

Pupa. Length: $3.5 \mathrm{~mm}$. Cephalic region: specimens with antennal sheath broken, length of cephalic setae: $0.05 \mathrm{~mm}$; full complement of cephalic, lower and lateral papillae; upper cephalic margin thickened laterally. Prothoracic spiracle setiform; length: $0.30-0.35 \mathrm{~mm}$. Wing sheath reaching basal $1 / 5$ of the abdominal segment 3; fore, mid and hind leg sheaths reaching basal $1 / 3 ; 1 / 2$ and distal $1 / 3$ of the abdominal segment 5 , respectively. Abdominal tergites $2-8$ with abundant dorsal spines, the proximal ones shorter than the distal spines (Fig. 24). 


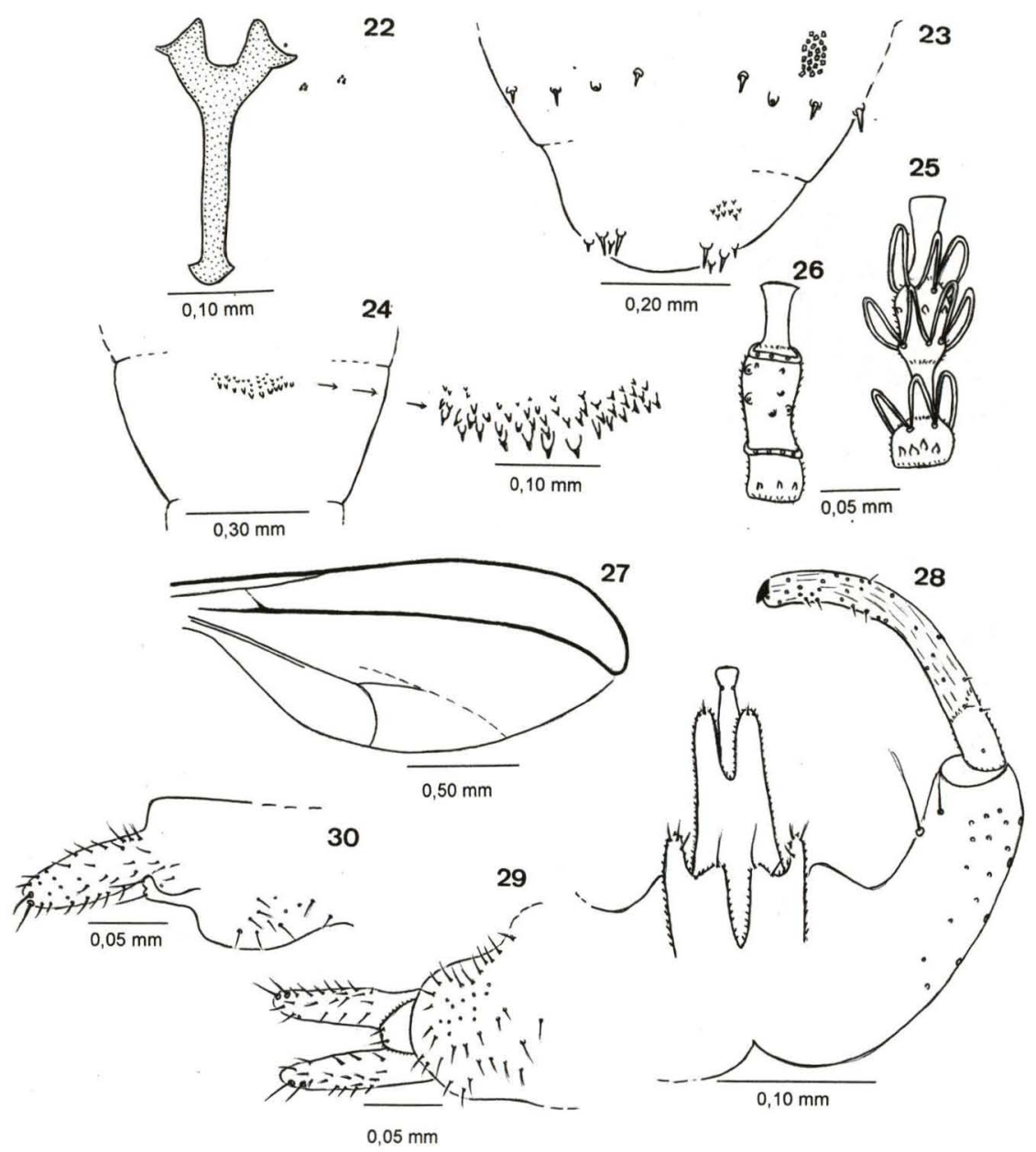

Figs 22-30. Clinodiplosis profusa sp. n. (22) Larva, spatula, sternal and lateral papillae (ventral); (23) larval posterior segments (dorsal); (24) pupa, abdominal segment VII (dorsal); (25) male, flagellomere $\mathrm{V} ;(26)$ female, flagellomere $\mathrm{V}$; (27) male, wing; (28) male terminalia (dorsal); (29) female terminalia (ventral); (30) female terminalia (lateral).

Adult. Head: Eyes with circular facets; male flagellomeres (Fig. 25): circumfila loops irregular in length; female flagellomeres (Fig. 26) with linear circumfila. Flagellomere necks bare. Flagellomere 12 with apical process. Frontoclypeus with eight long setae. Labrum triangular, greatly enlarged, with three pairs of ventral sensory setae and long, anteriorly directed lateral setulae. Hypopharynx 
of the same shape as labrum with long, anteriorly directed, lateral setulae. Labella elongate-convex, each with several long lateral setae and two short mesal sensory setae. Palpus with four setose, cylindrical and crescent segments, the basal ones wider than the distal.

Thorax. Wing (Fig. 27): length: 2.0-2.6 mm. Anepisternum with a few scales near middle. Anepimeron with vertical row of several setae. Tarsal claws thin, bent at basal third, simple on all legs. Empodia reaching to bend in claws.

Abdomen. Tergites 1-6 rectangular with double, complete row of caudal setae, several lateral setae, two basal trichoid sensilla, and elsewhere with scattered scales. Tergite 7 weakly sclerotized caudomesally, caudal setae and scales only present laterally; lateral setae and two basal trichoid present. Tergite 8 (male) unsclerotized rectangular with only basal trichoid sensilla for vestiture. Sternites 2-7 rectangular and setose, setae more abundant basally and mesally. Sternites 7-8 quadrate, each with caudal and midlength rows of setae and basal pair of trichoid sensilla. Female: tergites 1-7 as for 1-6 in male, sternites 2-7 as for 2-8 of male, tergite 8 unsclerotized, with a row of short caudal setae and basal pair of trichoid sensilla and short, scattered setae apically. Sternite 9 with scattered setae. Male terminalia (Fig. 28): gonocoxites not splayed and narrow; gonostylus elongate, narrow, bent at distal 1/3 and regular in width; cercus 2-lobed (outer lobe longer than the inner); hypoproct deeply bilobed and much longer than cercus; aedeagus elongate, narrow and constricted subapically. Ovipositor barely protrusible, female cerci separate, long, narrow and very setose, two setae longer than the others (Figs 29-30).

Material. Holotype male. BRAzIL, Rio de Janeiro: Maricá (Barra de Maricá), 05.X.1998 (emerg.: 28.X.1998), V. Maia leg., MNRJ. Paratypes: same locality, date and collector -1 male, 1 female, 1 pupal exuviae, MNRJ. Paratypes: same locality and collector: 2 males, 03.VII.1998 (emerg.: 1 on 21.IX.1998, 1 on 29.IX.1998); 4 females, 03.VII.1998 (emerg.: 2 on 03.IX.1998, 1 on 24.IX.1998, 1 on 29.IX.1998), 1 larva, 06.VI.1992, MNRJ.

Gall. Conical leaf gall; length: $0,6 \mathrm{~cm}$; width: $0,2 \mathrm{~cm}$; glabrous; monothalamous; green or red. Host Plant: Eugenia uniflora L. (Myrtaceae).

Etymology. The name profusa refers to the gall abundance.

Remarks. The larva of this species differs from other Clinodiplosis species in that the setae of the terminal segment are not each situated at the end of lobes. The pupa has enlarged dorsal spines on the abdomen, which is not common in species that pupate in the soil, as this one does. The hypoproct is notably elongate and its outer lobes are conspicuously longer than the inner ones. This species is the only Clinodiplosis known from Eugenia uniflora.

\section{Clusiamyia granulosa sp. $\mathbf{n}$.}

Figs 31-38

Larva. Body length: 3.1-3.6 mm. Colour: yellow. Spatula (length: 0.24-0.25 $\mathrm{mm}$ ) with two anterior, large, widely spaced teeth with many denticles between; stalk developed (Fig. 31). One group of three lateral papillae barely apparent on each side of spatula, two of the papillae with short setae. (Fig. 31). Terminal segment with two convex terminal lobes, each one with four terminal papillae without setae.

Revta bras. Zool. 18 (Supl. 1): 1 - 32, 2001 


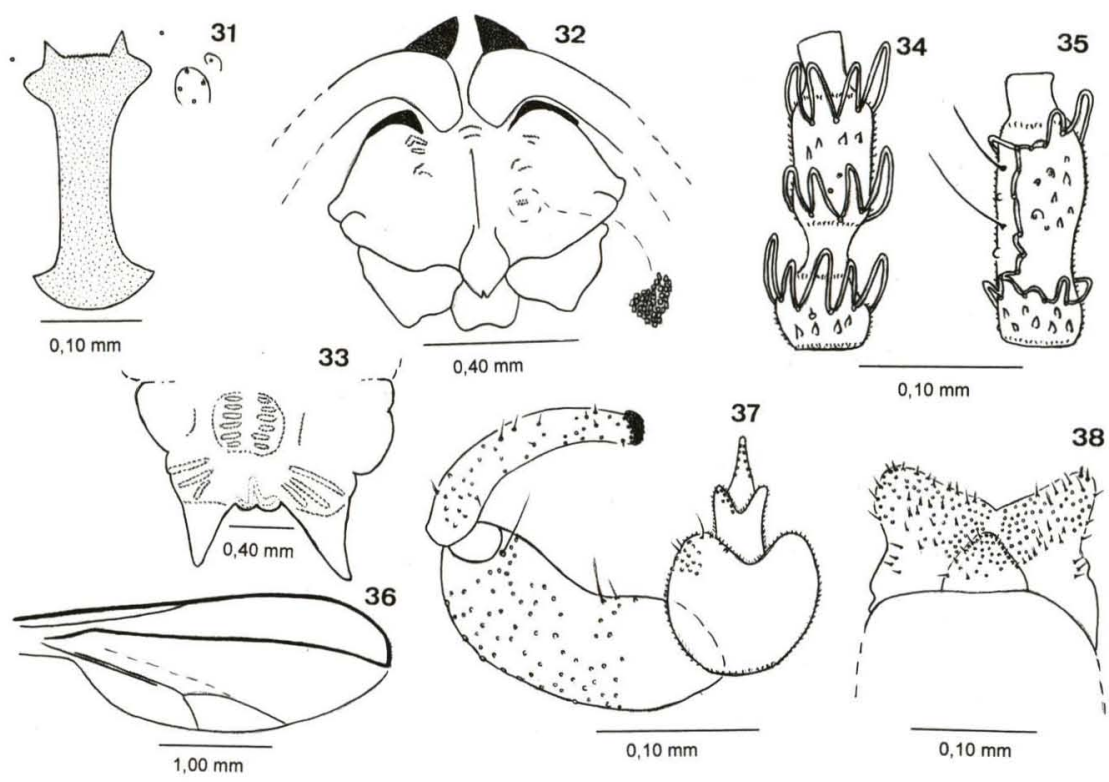

Figs 31-38. Clusiamyia granulosa sp. n. (31) Larva, spatula, sternal, lateral and ventral papillae (ventral); (32) pupa, cephalic region (ventral); (33) pupa, terminal segment (dorsal); (34) male, flagellomere $\mathrm{V} ;(35)$ female, flagellomere $\mathrm{V} ;(36)$ male, wing; (37) male terminalia (dorsal); (38) female terminalia (ventral).

Pupa. Length: 4.7-5.9 mm. Cephalic region (Fig. 32): antennal horn well developed, triangular and with 0.11-0.12 mm of length; cephalic seta nearly inconspicuous (length: $0.005 \mathrm{~mm}$ ); lower and lateral papillae absent; upper cephalic margin thickened laterally. Prothoracic spiracle very short (length: $0.03 \mathrm{~mm}$ ). Wing sheath reaching the basal $1 / 4$ of the abdominal segment III. Fore, mid and hind legs sheath reaching $1 / 2$ of the abdominal segment 4 , distal $5 / 7$ of the segment 4 and $1 / 2$ segment 5 , respectively. Abdominal tergites 2-8 with abundant spinules. Terminal segment with two esclerotized lobes (Fig. 33).

Adult. Head: Eyes with hexagonal facets. Male flagellomeres with circumfila loops subequal in length (Fig. 34). Female flagellomeres circumfila sinuous (Fig. 35). Frontoclypeus with 30-32 long setae. Labrum triangular, long-attenuate, with two pairs of ventral sensory setae and long, anteriorly directed lateral setulae. Hypopharynx of the same shape as labrum with long, anteriorly directed, lateral setulae. Labella elongate-convex, each with several long lateral setae and two short mesal sensory setae. Palpus with one segment conical in shape.

Thorax. Wing (Fig. 36): length: 3.3-4.0 mm; R5 longer than the wing, curved, joining $\mathrm{C}$ beyond wing apex; base of $\mathrm{M}$ straigth; Rs absent; $\mathrm{M} 3$ evanescent; $\mathrm{Cu}$ forked; Cup present. Anepisternum with a few scales near middle. Anepimeron with vertical row of several setae. Tarsal claws robust, bent at basal third, simple on all legs. Empodia approximately as long as claws. 
Abdomen. Tergites 1-6 rectangular with single, complete row of caudal setae, several lateral setae, two basal trichoid sensilla, and elsewhere with scattered scales. Tergite 7 wih caudal and lateral setae, two basal trichoid sensilla and elsewhere with scattered scales. Tergite 8 (male) unsclerotized rectangular with only basal trichoid sensilla and with some scales for vestiture. Sternites 2-6 rectangular and setose, setae more abundant basally and mesally. Sternites 7-8 quadrate, each with caudal and midlength rows of setae and basal pair of trichoid sensilla. Female: tergites $1-8$ as for $1-6$ in male, sternites $2-7$ as for $2-6$ of male, tergite 8 with a row of short caudal setae and basal pair of trichoid sensilla and short, scattered setae apically. Sternite 9 with scattered setae. Male terminalia (Fig. 37): gonocoxites splayed without mesobasal lobes; gonostylus elongate, discretely bent, and slightly constricted near the apex; cercus wide; hypoproct bilobed, appreciably shorter than aedeagus; aedeagus elongate and abruptly tapered near the apex. Ovipositor barely protrusible; female cerci wide, separate and with many setae (Fig. 38).

Material. Holotype male. BrazIL, Rio de Janeiro: Carapebus, 31.X.1998 (emerg.: 18.XI.1998), V. Maia leg., MNRJ. Paratypes: same locality, date and collector -2 males (emerg.: 31.X.1998; 08.XI.1998), 4 females (emerg.: 3 on 10.XI.1998 and 1 on 08.XI.1998) and 1 pupal exuviae (emerg.: 18.XI.1998), MNRJ. Paratypes: same locality and collector: 1 male, 25.VIII.1998 (emerg.: 15.XI.1998); 1 male, 25.IX.1998 (emerg.: 12.X.1998); 1 female, 25.IX.1998 (emerg.: 05.X. 1998); 2 pupal exuviae, 25.VIII.1998 (emerg.: 1 on 15.X.1998, I on 10.XI.1998); 1 larva 25.VII.1998; 2 larvae, 27.XI.1998; 1 larva, 26.II.1999, MNRJ.

Gall. Circular leaf gall (diameter: $1.0-1.5 \mathrm{~cm}$ ), glabrous, monothalamous and green. Host Plant: Clusia hilariana Schltdl. (Clusiaceae). head.

Etymology. The name granulosa refers to the grainy surface of the pupal

Remarks. The only other described congener, Clusiamyia nitida Maia is known from leaf galls on Clusia lanceolata collected in Restinga of Barra de Maricá (Rio de Janeiro, Brazil). The ovipositor and male terminalia of both are very similar but the hypoproct of Clusiamyia granulosa sp. $\mathbf{n}$. are deeply bilobed whereas in C. nitida, it is only slightly bilobed. Tarsal claws are simple in the new species and toothed in $C$. nitida. The two species have similar wing venation, a l-segmented palpus, male circumfila with short loops and sinuous female circumfila. The pupal frontal horn is present in C. nitida, but absent in C. granulosa sp. n. Antennal horns are wider in $C$. granulosa sp. n. Both species have a grainy pupal cephalic integument and lack abdominal spines. Larvae of the both species have a bilobed spatula (with more denticles between the two anterior teeth in C. granulosa sp. n.) and a similar complement of lateral and terminal papillae. Both species are associated with Clusia.

\section{Clusiamyia nitida Maia, 1996}

The larvae of $C$. nitida was unknown when that species was described. A description of the third instar is provided here.

Larva. Body length: 2.3-2.4 mm. Color: yellow. Spatula (length: 0.20-0.21 $\mathrm{mm}$ ) with two anterior, large, widely spaced teeth with $4-5$ small denticles between; stalk developed. One group of three lateral papillae barely apparent on each side of 
spatula, two of the papillae with short setae. Terminal segment with two convex terminal lobes, each one with four papillae without setae.

Material. BRAZIL, Rio de Janeiro: Maricá (Restinga of Barra de Maricá) - 4 larvae, 28.II.1996, V. Maia leg., MNRJ.

\section{Dasineura couepiae sp. $\mathbf{n}$.}

Figs $39-46$

Larva. Body length: $3.4 \mathrm{~mm}$. Color: yellow. Spatula 2-toothed, length: 0.25 $\mathrm{mm}$, apical tooth rounded at the apex, stalk developed (Fig. 39). Sternal papillae without seta. Four lateral papillae per side (two with seta). Three pairs of setose terminal papilla (one of them shorter than the others) (Fig. 40).

Pupa. Body length: $2.2 \mathrm{~mm}$. Cephalic region (Fig. 41 ): antennal horn reduced (length: $0.025 \mathrm{~mm}$ ); full complement of cephalic, lower and lateral facial papillae; cephalic seta with $0.06 \mathrm{~mm}$ of length; cephalic upper margin thickened laterally. Prothoracic spiracle setiform (length: $0.12 \mathrm{~mm}$ ). Wing sheath reaching the distal $1 / 4$ of the abdominal segment 3 . Fore, mid and hind legs sheath reaching the midlength of the abdominal segment 5 , the basal margin of the abdominal segment 6 and the distal margin of the same segment, respectively. Abdominal tergites II-VIII with numerous spinules.

Adult. Head: Eyes facets circular. 14-17 cylindrical flagellomeres with bare neck, the latter longer in male; circumfila similar in both sexes forming two undulate horizontal rings (Figs 42-43). Frontoclypeus with several long setae. Labrum triangular, long-attenuate, with three pairs of ventral sensory setae and long, anteriorly directed lateral setulae. Hypopharynx of the same shape as labrum with long, anteriorly directed, lateral setulae. Labella elongate-convex, each with several long lateral setae and two short mesal sensory setae. Palpus with four setose and crescent segment, the first one globular, the others cylindrical, the second the widest one.

Thorax. Wings (Fig. 44): length: 1.7-1.8 mm. Anepisternum with a few scales near middle. Anepimeron with vertical row of several setae. Tarsal claws thin, bent beyond its midlength, toothed on all legs. Empodia well developed, reaching to bend in claws.

Abdomen. Tergites 1-6 rectangular with single, complete row of caudal setae, 1-2 caudolateral setae per side, two basal trichoid sensilla and elsewhere with scattered scales. Tergite 7 short with only mesal pair of trichoid sensilla. Tergite 8 strap-like with only mesal pair of trichoid sensilla. Sternites 2-7 rectangular and setose, setae more abundant basally and mesally. Sternite 8 quadrate with caudal and midlength rows of setae and basal pair of trichoid sensilla. Female: tergites 1-6 as in male, sternites 2-7 as in male, tergite 7 rectangular with numerous caudal and lateral setae, tergite 8 longitudinal divided. Sternite 9 with scattered setae. Male terminalia (Fig. 45): gonocoxite not splayed, gonostylus wider basally and progressively tapering to apex; cercus triangular; hypoproct strongly bilobed (lobes tiny and digitform); parameres elongate; aedeagus straight at the apex. Ovipositor elongate-protrusible, female cerci ovoid (Fig. 46). 


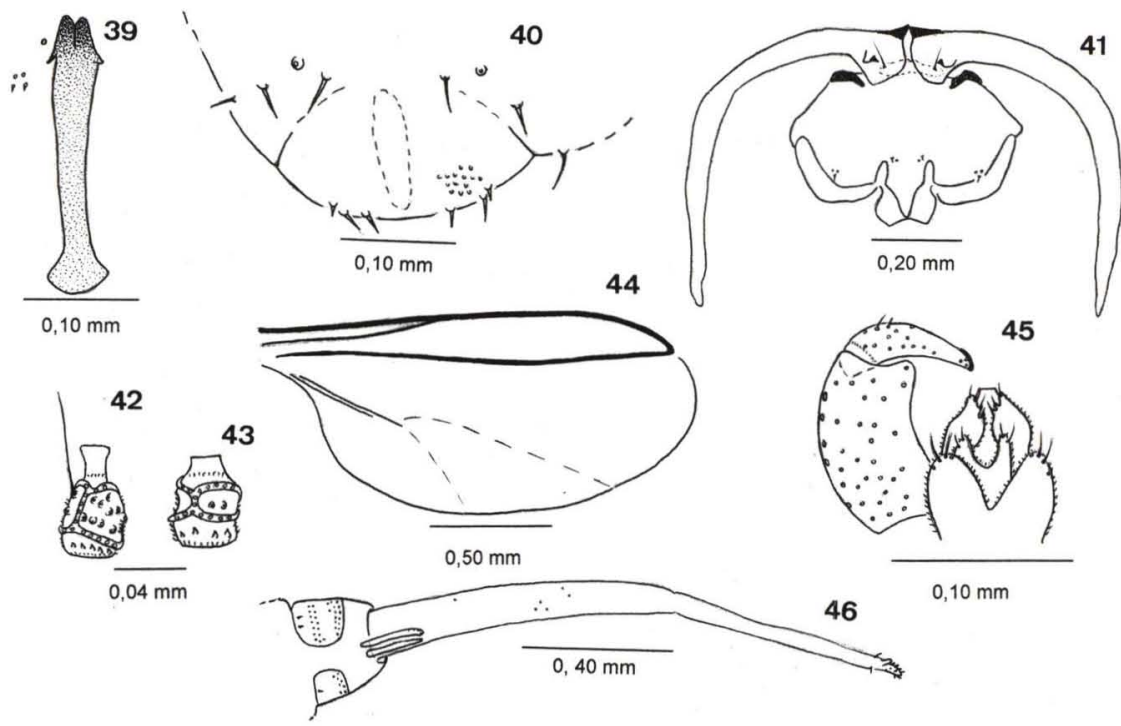

Figs 39-46. Dasineura couepiae sp. n. (39) Larva, spatula, sternal and lateral papillae (ventral); (40) larva, posterior segments (ventral); (41) pupa, cephalic region (ventral); (42) male, flagellomere $\mathrm{V}$; (43) female, flagellomere $\mathrm{V}$; (44) male, wing; (45) male terminalia (dorsal); (46) female terminalia (dorsal).

Material. Holotype male. BRAZIL, Rio de Janeiro: Maricá (Barra de Maricá), 05.VI.1998 emerg.: 10.VII.1998), V. Maia leg., MNRJ. Paratypes: same locality, date and collector - 4 females (emerg.: 10.VII.1998, 12.VII.1998); 1 pupa; 3 pupal exuviae and 1 larva. Paratypes: same locality and collector: 1 male, 15.XII.1989, MNRJ.

Gall. Circular leaf gall, projected on both surfaces (diameter: $0.4 \mathrm{~cm}$ ), glabrous, monothalamous and green. Host Plant: Couepia ovalifolia (Schoot) Benth. (Chrysobalanaceae).

Etymology. The name couepiae is the genitive of the host plant name.

Remarks. The larva of this species has only three pairs of papillae on the terminal segment unlike most known species that have four pairs. No other Dasineura is known from the Chrysobalanaceae.

\section{Epihormomyia miconiae sp. $\mathbf{n}$.}

Figs 47-56

Larva. Body length: 3.8-4.2 mm. Color: orange. Spatula 2-toothed (teeth wide), enlarged anteriorly; length: $0.20-0.25 \mathrm{~mm}$ (Fig. 47). Sternal papillae without seta and full complement of lateral papillae (Fig. 47). Terminal segment as in figure 48.

Pupa. Length: $2.55 \mathrm{~mm}$. Cephalic region (Fig. 49): antennal horn reduced, simple and rounded, with 0.03-0.04 mm of length; cephalic seta with $0.12 \mathrm{~mm}$ of length; full complement of cephalic, lower and lateral papillae; upper cephalic margin thickened laterally; cephalic seta with 0.03-0.04 mm of length. Prothoracic 

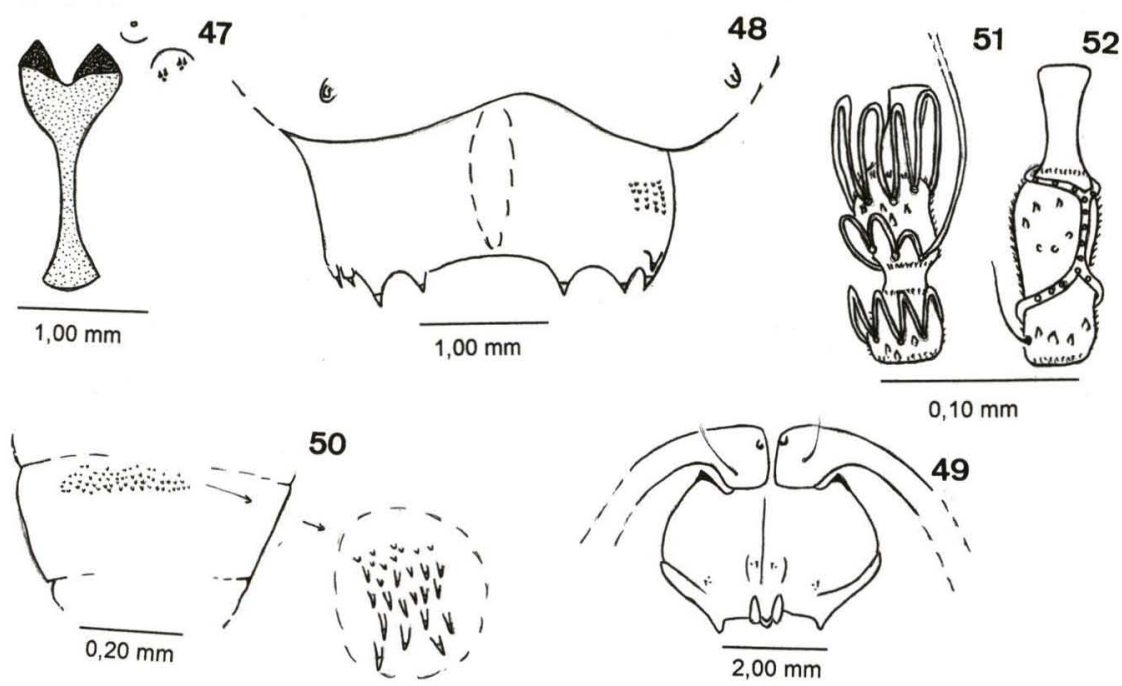

Figs 47-52. Epihormomyia miconiae sp. n. (47) Larva, spatula, sternal and lateral papillae (ventral); (48) larva, posterior segments (ventral); (49) pupa, cephalic region (ventral); (50) pupa, abdominal segment VII (dorsal); (51) male, flagellomere V; (52) female, flagellomere V.

spiracle setiform; length: $0.08 \mathrm{~mm}$. Wing sheath reaching $1 / 2$ of the abdominal segment 3 ; fore, mid and hind leg sheaths reaching basal $1 / 3 ; 1 / 2$ and distal margin of the abdominal segment 6 , respectively. Abdominal tergites 2-8 with abundant dorsal spines, the proximal shorter than the distal ones (Fig. 50).

Adult. Head: Eyes facets circular; male flagellomeres (Fig. 51): circumfila loops irregular in length; female flagellomeres (Fig. 52) with two undulate horizontal rings. Flagellomeres necks bare. Flagellomere 12 with apical process. Frontoclypeus with 12-14 long setae. Labrum triangular, long-attenuate, with three pairs of ventral sensory setae and long, anteriorly directed lateral setulae. Hypopharynx of the same shape as labrum with long, anteriorly directed, lateral setulae. Labella elongate-convex, each with several long lateral setae and two short mesal sensory setae. Palpus with three setose and crescent segments: first globular, second and third cylindrical.

Thorax. Wing (Fig. 53): length: 1.8-2.4 mm. Anepisternum with a few scales near middle. Anepimeron with vertical row of several setae. Tarsal claws thin, bent at basal third, toothed on all legs. Empodia reaching to bend in claws.

Abdomen. Tergites 1-6 rectangular with single, complete row of caudal setae, several lateral setae, two basal trichoid sensilla, and elsewhere with scattered scales. Tergite 7 weakly sclerotized caudomesally with few scattered caudal and lateral setae and two basal trichoid sensilla. Tergite 8 (male) band-like with only basal trichoid sensilla for vestiture. Sternites 2-6 rectangular and setose, setae more abundant basally and mesally. Sternites 7-8 quadrate, each with caudal and midlength rows of setae and basal pair of trichoid sensilla. Female: tergites 1-7 as for 1-6 in male, sternites 2-7 as for 2-6 of male, tergite 8 unsclerotized, with a row of short caudal setae and basal pair of trichoid sensilla and short, scattered setae 

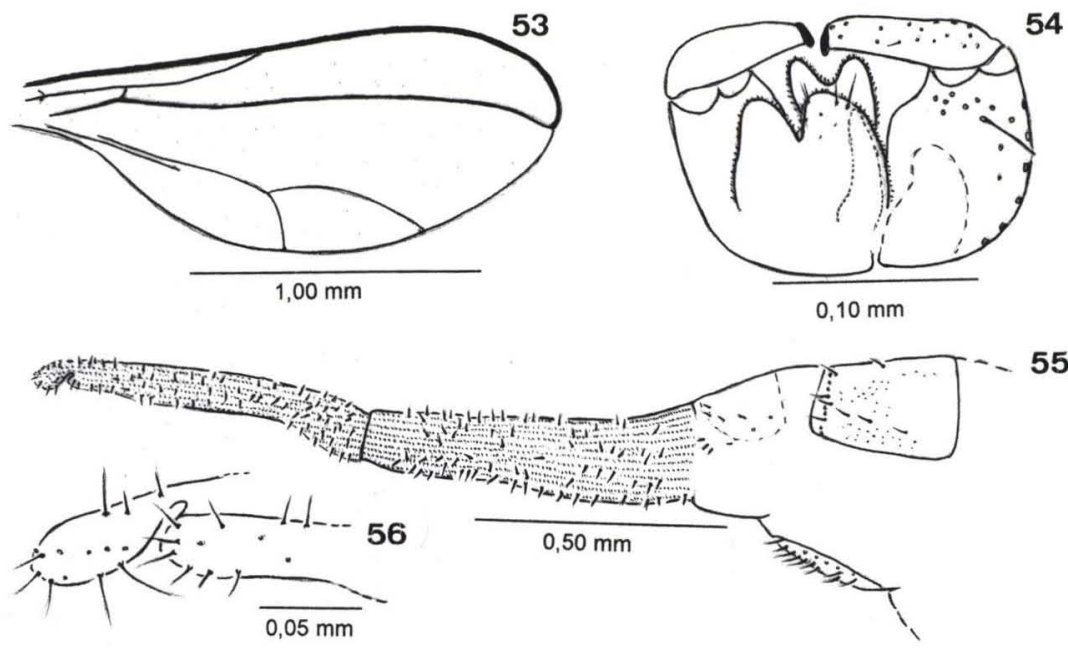

55

Figs 53-56. Epihormomyia miconiae sp. n. (53) Male, wing; (54) male terminalia (dorsal); (55) female terminalia (lateral); (56) female, cercus (lateral).

apically. Sternite 9 with scattered setae. Male terminalia (Fig. 54): gonocoxites splayed and wide; gonostylus stout and not bent; cercus rounded; hypoproct bilobed and setose; hypoproct slightly longer than cercus; parameres absent; aedeagus short and narrow, tapering progressively to apex. Ovipositor very protrusible, female cerci separate, rounded and setose (Fig. 55-56).

Material. Holotype male. BRAZIL, Rio de Janeiro: Carapebus, 31.X.1998 (emerg.: 06.XI.1998), V. Maia leg., MNRJ. Paratypes: same locality, date and collector - 4 females (emerg.: 1 on 31.X.1998, 1 on 06.XI.1998, 2 on 08.XII.1998), 1 pupal exuviae (emerg.: 06.XI.1998), MNRJ. Paratypes: same locality and collector: 1 male, 28.XI.1998 (emerg.: 08.XII.1998); 1 larva, 29.VI.1998; 1 larva, 25.IX.1998; 1 larva, 29.I.1999; 1 larva, 30.I.1999, MNRJ.

Gall. Ovoid bud gall; length: $0.8-1.1 \mathrm{~cm}$; width: $0.3-0.6 \mathrm{~cm}$; glabrous, monoor polithalamous; green. Host Plant: Miconia cinnamomifolia (DC.) Naudin. (Melastomataceae).

Etymology. The name miconiae is the genitive of the host plant name.

Remarks. This species is the second described species of Epihormomyia Felt, 1915. The previous one - E. auripes Felt, 1915 - is known from a single female caught in flight, in Guyana. Both species differ in the shape of the female flagellomeres (binodal in E. auripes and cylindrical in E. miconiae sp. n.), in wing venation (M3 present in E. auripes and absent in E. miconiae sp. n.), in the number of teeth on the tarsal claws (two in E. auripes and one in E. miconiae sp. n.) and in the length of the ovipositor (longer in E. miconiae sp. n.). Both have a three segmented palpus; spurred first tarsomeres; claws that toothed and bent near the base; empodia as long as the bend in claws; the R5 longer than the wing and joining $\mathrm{C}$ beyond the wing apex; Rs partially as strong as R1, but weak anteriorly and separate female cerci. 


\section{Lopesia grandis sp. $\mathbf{n}$.}

Figs $57-65$

Larva. Body length: 3.0-4.3 mm. Color: yellow. Spatula 4-toothed, length: 0.24-0.26 mm, inner tooth larger than the outer ones, a small denticule between the outer and inner tooth is present, outer tooth divergent (Fig. 57). Two pairs of setose lateral papillae equal in size per side (Fig. 57). Two pairs of terminal papillae (Fig. $58)$.

Pupa. Length: 3.3-3.5 mm. Cephalic region (Fig. 59): antennal horn simple with $0.05 \mathrm{~mm}$ of length; full complement of lower and lateral papillae; upper cephalic margin thickened laterally; cephalic seta with $0.03-0.04 \mathrm{~mm}$ of length. Upper frontal spine triangular and with $0.03-0.04 \mathrm{~mm}$ of length. Prothoracic spiracle setiform and well developed (length: $0.24-0.29 \mathrm{~mm}$ ). Wing sheath reaching $1 / 2$ of the abdominal segment 3 ; fore and mid leg sheaths subequal in length, reaching basal $1 / 5$ of the abdominal segment 6 ; hind leg sheath reaching basal $1 / 3$ of the same segment. Abdominal tergites 2-8 with abundant dorsal spines, the proximal ones shorter than the distal spines (Fig. 60).

Adult. Head: Eyes facets hexagonal; male flagellomeres (Fig. 61): each with three circumfila with short loops, nearly linear; female flagellomeres (Fig. 62): anastomosing circumfila. Flagellomere necks bare. Flagellomere 12 with apical process. Frontoclypeus with five setae. Labrum triangular, long-attenuate, with two pairs of ventral sensory setae and long, anteriorly directed lateral setulae. Hypopharynx of the same shape as labrum with long, anteriorly directed, lateral setulae. Labella elongate-convex, each with several long lateral setae and two short mesal sensory setae. Palpus: segments 1 and 2 globular, 3 and 4 cylindrical, the third the longest one and the fourth the widest one.

Thorax. Wing (Fig. 63): length: 2.7-3.4 mm. Anepisternum with a few scales near middle. Anepimeron with vertical row of several setae. Tarsal claws bent at basal third, toothed on all legs. Empodia reaching to bend in claws.

Abdomen. Tergites 1-6 rectangular with single, complete row of caudal setae, several lateral setae, two basal trichoid sensilla, and elsewhere with scattered scales. Tergite 7 rectangular with two basal trichoid sensilla. Tergite 8 (male) unsclerotized rectangular with only basal trichoid sensilla for vestiture. Sternites 2-6 rectangular and setose, setae more abundant basally and mesally. Sternites 7-8 quadrate, each with caudal and midlength rows of setae and basal pair of trichoid sensilla. Female: tergites 1-7 as for 1-6 in male, sternites 2-7 as for 2-6 of male, tergite 8 unsclerotized with a basal pair of trichoid sensilla. Sternite 9 with scattered setae. Male terminalia (Fig. 64): gonocoxites splayed with a small mesobasal lobe; gonostylus elongate, narrow, regular in length and bent at distal 1/3; cercus rounded and hypoproct bilobed; parameres absent; aedeagus elongate and tapering progressively to apex. Ovipositor barey protrusible, female cerci separate, wide and very setose (Fig. 65).

Material. Holotype male. BrazIL, Rio de Janeiro: Carapebus, 28.VI.1998 (emerg.: 12.X.1998), V. Maia leg., MNRJ. Paratypes: same locality, date and collector -2 females (emerg.: 29.VI.1998 and 27.XI.1998), 5 pupal exuviae, MNRJ. Paratypes: same locality and collector: 2 males, 29.VI.1998 (emerg.: 09.VII.1998); 1 male, 


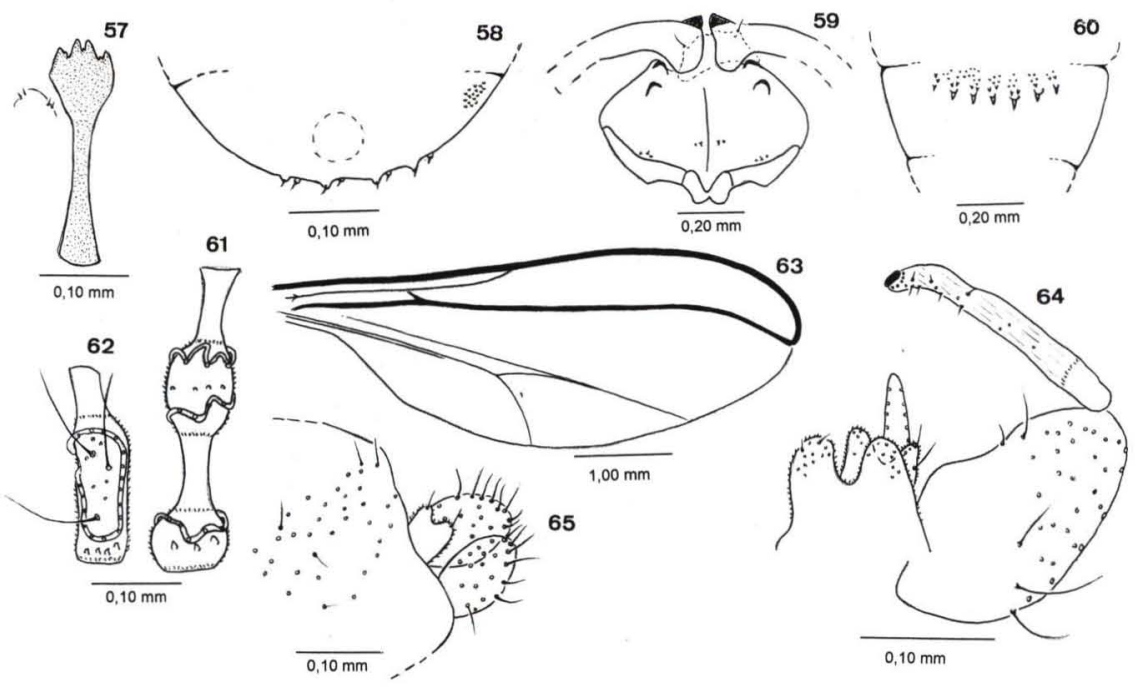

Figs 57-65. Lopesia grandis sp. n. (57) Larva, spatula, sternal and lateral papillae (ventral); (58) larva, posterior segment (ventral); (59) pupa, cephalic region (ventral); (60) pupa, abdominal segment VII (dorsal); (61) male, flagellomere $\mathrm{V}$; (62) female, flagellomere $\mathrm{V}$; (63) male, wing; (64) male terminalia (dorsal); (65) female cerci and hypoproct (ventral).

25.IX.1998 (emerg.: 30.IX.1998); 1 male, 27.XI.1998; 1 female, 27.XI.1998; 2 pupal exuviae, 29.VII.1998 (emerg.: 09.VII.1998); 1 larva, 29.VI.1998; 1 larva, 27.XI.1998, MNRJ. Additional material: BRAZIL, Rio de Janeiro: Rio de Janeiro (Parque Chico Mendes) - 4 larvae, M. A. P. de Azevedo leg., 31.III.2000.

Gall. discoid leaf gall; diameter: $0.4 \mathrm{~cm}$; glabrous, monothalamous; green. It occurs only on the leaf inferior surface. Host Plant: Dalbergiamyia ecastophylla L. Taub (Leguminosae).

Etymology. The name grandis refers to the length of the species.

Remarks. This species differs from other known Lopesia in having 4-toothed spatula (larva), upper frontal spine (pupa) and circumfila loops very short (male). This is the first Lopesia species known to feed on Leguminosae.

\section{Lopesia marginalis sp. $\mathbf{n}$.}

Figs 66-74

Larva. Body length: 3.0-4.4 mm. Color: yellow. Spatula 2-toothed, length: 0.19-0.29 mm, apical tooth pointed and close each one from other; stalk developed (Fig. 66). Full complement of lateral papillae. Terminal papillae corniform, each one in a projection (Fig. 67).

Pupa. Body length: 3.8-4.1 mm. Cephalic region (Fig. 68): antennal horn reduced to a marginal thickened; cephalic seta with $0.06-0.08 \mathrm{~mm}$ of length; full complement of lower and lateral facial papillae. Prothoracic spiracle setiform and relatively short (length: $0.25-0.26 \mathrm{~mm}$ ). Wing sheath reaching the basal $1 / 4$ of the 

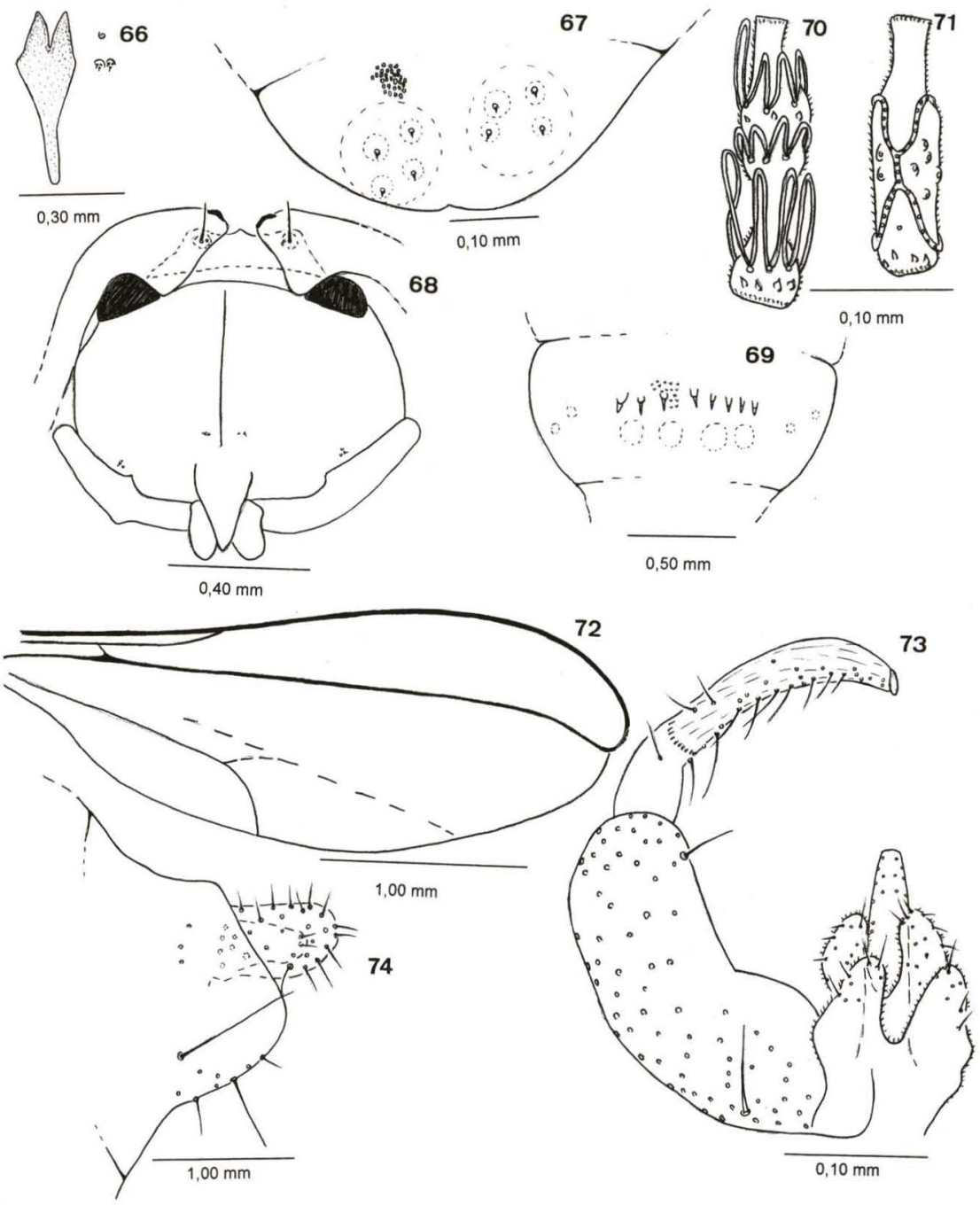

Figs 66-74. Lopesia marginalis sp. n. (66) Larva, spatula, sternal and lateral papillae (ventral); (67) larva, posterior segment (ventral); (68) pupa, cephalic region (ventral); (69) pupa, abdominal segment $\mathrm{V}$ (dorsal); (70) male, flagellomere $\mathrm{V}$; $(71)$ female, flagellomere $\mathrm{V} ;(72)$ male, wing; (73) male terminalia, dorsal; (74) female terminalia (lateral).

abdominal segment 3 . Fore, mid and hind legs sheath reaching the basal $1 / 3,1 / 2$ and the distal $1 / 3$ of the segment 6 , respectively. Abdominal tergites 2-8 with an irregular row of well developed spines. Spines scarce in segments 6 and 7, segment 8 with 7-8 spines (Fig. 69).

Adult. Head: Eyes facets hexagonal. Flagellomeres binodal and tricircumfilar in male, loops of second circumfila shorter than the others, not reaching the distal 
circumfila base (Fig. 70); in female: circumfila as in figure 71; flagellomeres necks setulose in both sexes. Frontoclypeus with few setae ( 2 pairs). Labrum triangular, long-attenuate, with three pairs of ventral sensory setae and long, anteriorly directed lateral setulae. Hypopharynx of the same shape as labrum with long, anteriorly directed, lateral setulae. Labella elongate-convex, each with several long lateral setae and two short mesal sensory setae. Palpus with four crescent and setose segments: the first one globular, the others cylindrical; the second the widest one.

Thorax. Wings (Fig. 72): length: 2.8-3.1 mm. Anepisternum with a few scales near middle. Anepimeron with vertical row of several setae. Tarsal claws thin, bent beyond its midlength, simple on all legs. Empodia not reaching to bend in claws.

Abdomen. Tergites 1-6 rectangular with single, complete row of caudal setae, several lateral setae, two basal trichoid sensilla, and elsewhere with scattered scales. Tergite 7 weakly sclerotized with only two basal trichoid sensilla. Tergite 8 (male) unsclerotized rectangular with only basal trichoid sensilla for vestiture. Sternites 2-7 rectangular and setose, setae more abundant basally and mesally. Sternite 8 quadrate, with caudal and midlength rows of setae and basal pair of trichoid sensilla. Female: tergites 1-7 as for 1-6 in male, sternites 2-7 as for 2-8 of male, tergite 8 unsclerotized, with a row of short caudal setae and basal pair of trichoid sensilla and short, scattered setae apically. Sternite 9 with scattered setae. Male terminalia (Fig. 73): gonocoxites splayed, gonostylus slightly wider basally; cercus triangular; hypoproct deeply bilobed (lobes rounded at apex); parameres absent; aedeagus elongate. Ovipositor barely protrusible, female cerci ovoid (Fig. 74).

Material. Holotype male. BraziL, Rio de Janeiro: Maricá (Barra de Maricá), 02.XII.1989, V. Maia leg., MNRJ. Paratypes: same locality, date and collector - 1 male, 3 females, 5 larvae and 2 pupal exuviae, MNRJ. Paratypes: same locality and collector: 1 male, II.1998; 2 females, 08.I.1998; 1 pupa, II.1998; 1 pupal exuviae, II.1998; 1 pupal exuviae, 14.III.1998;1 pupal exuviae, 08.IX.1998) and 1 larva,II.1998, MNRJ.

Gall. Marginal leaf roll (length: $0.8-1.5 \mathrm{~cm}$; width: $0.1-0.3 \mathrm{~cm}$ ), glabrous, monothalamous and green. Host Plant: Couepia ovalifolia (Schott) Benth (Chrysobalanaceae).

Etymology. The name marginalis refers to the placement of the gall at the margin of the leaf.

Remarks. Lopesia marginalis $\mathbf{s p .} \mathbf{n}$. is distinctive for the shape of its spatula. This is the second species of Lopesia known on Chrysobalanaceae. The other $-L$. licaniae Gagné, 1996 - induces stem galls on Licania michauxii in Florida.

\section{Lopesia singularis sp. $\mathbf{n}$.}

\section{Figs $75-81$}

Larva. Body length: 1.9-2.4 mm. Color: yellow. Spatula absent. Full complement of lateral papillae. Terminal segment with two lobes, each one with three setose papillae (one longer than the others) (Fig. 75).

Pupa. Length: 3.3-4.1 mm. Cephalic region (Fig. 76): antennal base not greatly modified, rounded anteriorly and with a small ventral point; full complement of 


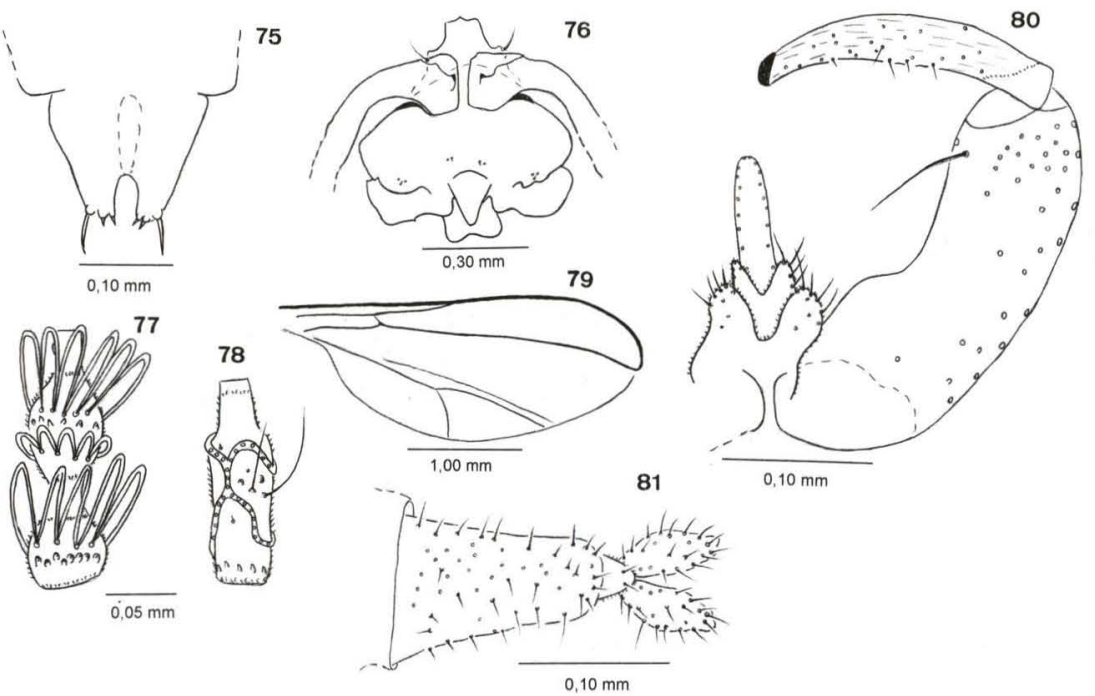

Figs 75-81. Lopesia singularis sp. n. (75) Larva, posterior segment (ventral); (76) pupa, cephalic region (ventral); (77) male, flagellomere $\mathrm{V}$; (78) female, flagellomere $\mathrm{V}$; (79) male, wing; (80) male terminalia, dorsal; (81) female terminalia (ventral).

cephalic, lower and lateral papillae; cephalic seta measuring 0.06-0.07 mm; upper cephalic margin thickened laterally. Prothoracic spiracle with $0.20-0.24 \mathrm{~mm}$ of length. Wing sheath reaching basal $1 / 4$ of the abdominal segment 3 ; fore, mid and hind leg sheaths reaching distal margin of the segment 4 , basal $1 / 6$ of the segment 5 and $1 / 2$ of the same segment, respectively. Abdominal tergites 2-8 with tiny spicules.

Adult. Head: Occipital process present. Eyes facets circular; male flagellomeres: loops of second circumfila shorter than the others (Fig. 77); female flagellomere as in figure 78. Frontoclypeus with few setae. Labrum triangular, long-attenuate, with many ventral sensory setae and lateral setulae. Hypopharynx of the same shape as labrum with lateral setulae. Labella elongate-convex, each with several lateral and few mesal sensory setae. Palpus: first and second segments cylindrical, third claviform. First segment about 1.8 times as long as wide (length: $0.01 \mathrm{~mm}$ ); second about 2.8 times as long as wide, regular in wide (length: $0.02 \mathrm{~mm}$ ); third gradually widening to the apex, about three times as long as wide, all covered with setulae and setae.

Thorax. Wing (Fig. 79): length: 2.4-2.9 mm. Anepisternum with a few scales near middle. Anepimeron with vertical row of several setae. Tarsal claws thin, bent at basal third, toothed on all legs. Empodia not reaching beyond bend in claws.

Abdomen. Tergites 1-6 rectangular with single, complete row of caudal setae, several lateral setae, two basal trichoid sensilla, and elsewhere with scattered scales. Tergite 7 rectangular, weakly sclerotized caudomesally, caudal setae and scales only present laterally; lateral setae and two basal trichoid present. Tergite 8 (male) unsclerotized rectangular with only basal trichoid sensilla for vestiture. Sternites 2-6 rectangular and setose, setae more abundant basally and mesally. 
Sternite 7-8 quadrate, each with caudal and midlength rows of setae and basal pair of trichoid sensilla. Female: tergites 1-7 rectangular and setose, setae more abundant basally and mesally, tergite 8 unsclerotized, with a row of short caudal setae and basal pair of trichoid sensilla and short, scattered setae apically. Sternite 9 with scattered setae.

Male terminalia (Fig. 80): gonocoxites narrow and splayed; gonostylus elongate, narrow, discretely bent and wider in the medial $1 / 3$; cercus wider and shorter than hypoproct; aedeagus remarkably longer than hypoproct. Ovipositor barely protrusible, female cerci setose (2 setae longer than the others) and separate (Fig. 81).

Material. Holotype male. BraziL, Rio de Janeiro: Maricá (Itaipuaçu), 04.IX.1998 (emerg.: 09.IX.1998), V. Maia leg., MNRJ. Paratypes: same locality, date and collector -2 female (emerg.: 09.IX.1998), MNRJ. Paratypes: same locality and collector: 3 males, 10.VII.1997 (emerg.: 23.VII.1998); 2 females, 10.VII.1997 (emerg.: 23.VII.1998), 5 pupal exuviae, 10.VII.1997 (emerg.: 23.VII.1998), MNRJ. Paratypes - BRAZIL, Rio de Janeiro: Maricá (Barra de Maricá), same collector: 1 male, 22.IX.1987; 1 larva, 03.VII.1998, 3 larvae, 23.VII.1998, MNRJ.

Gall. Circular leaf gall (diameter: $0.4-0.5 \mathrm{~cm}$ ), glabrous, monothalamous and green. Host Plant: Pouteria venosa (Mart.) Baehni (Sapotaceae).

Etymology. The name singularis refers to the uncommon terminal segment of larvae.

Remarks. Lopesia singularis sp. $\mathbf{n}$. is distinctive for its larval terminal segment. This is the first species of Lopesia known from Sapotaceae.

\section{Manilkaramyia gen. $\mathbf{n}$.}

Larva. Cylindrical shaped and of regular width. Spatula with two pointed teeth, not close to each other. Sternal papillae without seta. Four pairs of lateral papillae per side.

Pupa. One pair of setose lateral papillae; lower facial papillae absent. Antennal horn triangular and reduced. Upper cephalic margin thickened laterally. Prothoracic spiracle reduced to a dark spot. Abdominal segments 2-8 with tiny spinules. Terminal segment bilobed in both sexes.

Adult. Head: Occipital process absent; palpus with three setose segments; male flagellomeres binodal and tricircumfilar; female flagellomere cylindrical and circumfila linear; flagellomere necks elongate and bare in both sexes.

Thorax. Wing: R5 elongate, slightly bent, joining $C$ just beyond wing apex; Rs partially as strong as R1, but weak anteriorly; base of M slight curve; M3 evanescent; $\mathrm{Cu}$ forked; CuP present. First tarsomeres without spur; tarsal claws simple and curved beyond its midlength; empodia reaching claws curvature.

Abdomen. Gonocoxites wide and not splayed, gonostylus with serrated teeth; cercus triangular and hypropoct bilobed and setose; aedeagus elongate rounded apically; cercus, hypoproct and aedeagus subequal in length. Ovipositor protrusible and striated, female cercus separate and tiny.

Remarks. The number and shape of the flagellomeres place this genus among the Cecidomyiidi, but it does not fit in any known tribe. Manilkaramyia gen. $\mathbf{n}$. will 
key to Anasphodiplosis Blanchard, 1939 in couplet 66 of GAGNÉ (1994), if one ignores the shape of R1 and the host plant. Both genera have ovipositor and tarsal claws very similar in shape, but the wing venation is conspicuously different. The new genus is associated with Sapotaceae, whereas Anasphodiplosis occurs on Apocynaceae.

Type species: Manilkaramyia notabilis $\mathbf{s p .} \mathbf{n}$.

Etymology. Manilkaramyia refers to the generic name of the host plant + myia.

\section{Manilkaramyia notabilis sp. $\mathbf{n}$.}

Figs $82-88$

Larva. Body length: 2.6-4.0 mm. Color: yellow. Spatula length: 0.29-0.38 $\mathrm{mm}$; stalk reduced (Fig. 82). Sternal papillae asetose and four lateral papillae asetose on each side of the spatula (Fig. 82). Terminal papillae not visible.

Pupa. Length: 3.6-5.2 mm. Cephalic region (Fig. 83): antennal horn reduced meauring $0.02 \mathrm{~mm}$; cephalic papillae with the full complement; cephalic seta short (length: $0.01 \mathrm{~mm}$ ); one pair of setose lower facial papillae; lateral papillae absent; upper cephalic margin thickened laterally. Wing sheath reaching basal $1 / 3$ of the abdominal segment 3; fore, mid and hind leg sheaths reaching basal $1 / 4$ of the segment 4 , distal $1 / 5$ of the same segment and basal $1 / 6$ of segment 5 , respectively. Abdominal tergites 2-8 with tiny spicules.

Adult. Head: Occipital process absent. Eyes facets circular; male flagellomeres binodal and tricircumfilar; male flagellomeres necks, except in the flagellomere 12 (setulose); female flagellomeres cylindrical with linear circumfila and bare necks (Figs 84-85). Frontoclypeus with several long setae. Labrum triangular, long-attenuate, with three pairs of ventral sensory setae and long, anteriorly directed lateral setulae. Hypopharynx of the same shape as labrum with long, anteriorly directed, lateral setulae. Labella elongate-convex, each with several long lateral setae and two short mesal sensory setae. Palpus: segments subequal in width, segments 1-2 globular, segment 3 cylindrical.

Thorax. Wing (Fig. 86): length: 2.5-3.4 mm. Anepisternum with a few scales near middle. Anepimeron with vertical row of several setae. Tarsal claws bent beyond its midlength, simple on all legs. Empodia reaching to bend in claws.

Abdomen. Tergites 1-7 rectangular with single, complete row of caudal setae, several lateral setae, two basal trichoid sensilla, and elsewhere with scattered scales. Tergite 8 (male) unsclerotized rectangular with only basal trichoid sensilla for vestiture. Sternites 2-7 rectangular and setose, setae more abundant basally and mesally. Sternite 8 quadrate scattered setae and a basal pair of trichoid sensilla. Female: tergites 1-7 as in male, sternites 2-7 as in male, tergite 8 unsclerotized with a basal pair of trichoid sensilla. Male terminalia (Fig. 87): gonocoxites wide and not splayed; gonostylus stout and strongly bent; cercus about as wide as hypoproct; aedeagus narrow, wider to apex and rounded apically; cercus, hypoproct and aedeagus subequal in length. Ovipositor protrusible with elongate ventral setae, female cerci setose, separate and tiny, setae more abundant ventrally (Fig. 88). 


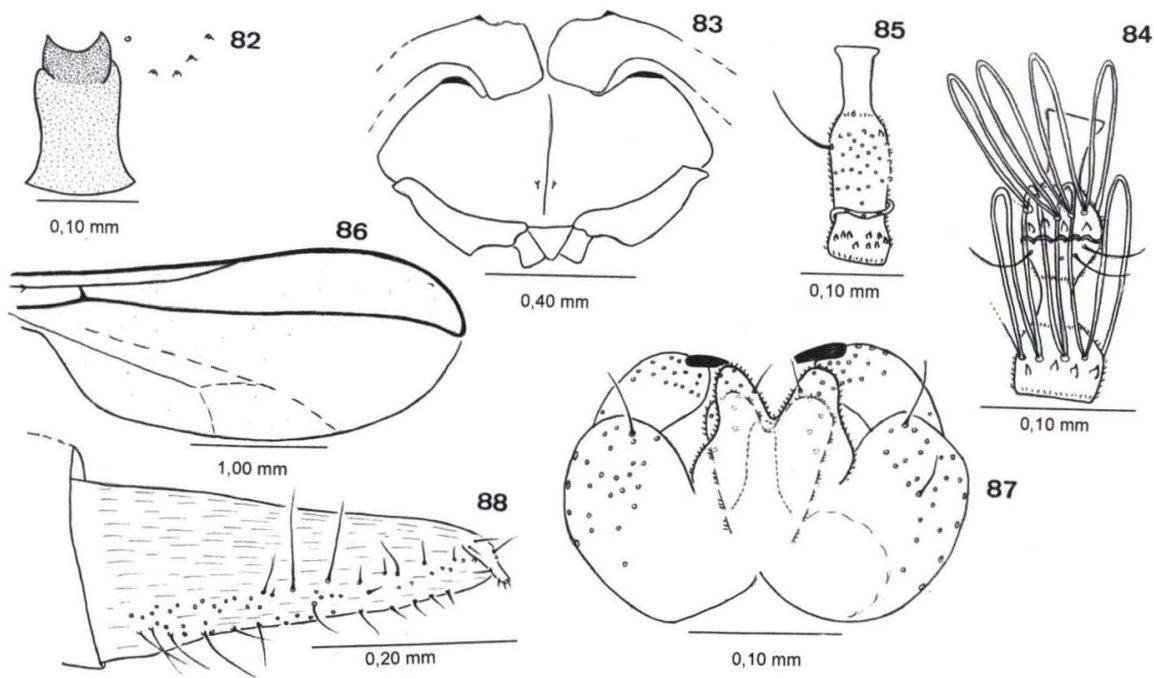

Figs 82-88. Manilkaramyia notabilis sp. n. (82) larva, spatula, sternal and lateral papillae (ventral); (83) pupa, cephalic region (ventral); (84) male, flagellomere $\mathrm{V}$; (85) female, flagellomere $V_{\text {; }}(86)$ male, wing; (87) male terminalia, dorsal; (88) female terminalia (lateral).

Material. Holotype male. BRAZIL, Rio de Janeiro: Carapebus, 25.IX.1998, V. Maia leg., MNRJ. Paratypes: same locality, datê and collector - 2 larvae. Paratypes: same locality and collector: 2 males, 29.VIII.1998 (emerg.: 30.VIII. 1998); 1 male, 31.X.1998 (emerg.: 04.XI.1998), 1 male, 27.II.1998; 1 female, 29.VIII. 1998 (emerg.: 30.VIII.1998); 1 female, 31.X.1998 (emerg.: 04.XI.1998); 3 pupal exuviae, 29.VIII.1998 (emerg.: 30.VIII.1998); 2 pupal exuviae, 31.X.1998 (emerg.: 04.XI.1998); 1 larva, 29.VI.1998; 1 larva, 29.VIII.1998; 2 larvae, 25.IX. 1998; 3 larvae, 17.III.1999, MNRJ.

Gall. Ovoid bud gall with a spine-like projection at the apex (length: $0.7 \mathrm{~cm}$; width: $0.3 \mathrm{~cm}$ ), glabrous, bi- or monothalamous and green. Host Plant: Manilkara subsericea (Mart.) Dubard. (Sapotaceae).

Etymology. The name notabilis refers to the gall conspicuousness.

\section{Mayteniella gen. $\mathbf{n}$.}

Larva. Cylindrical shaped, slightly tapering to posterior end. Integument: dorsal view intensely grainy, except in the discal area of each segment, where there is a plate strongly sclerotized. Spatula with two teeth well developed and splayed; stalk shorter than the tooth. Papillae not visible (due to the integumentar grains).

Pupa. Lower and lateral papillae absent. Antennal horn simple and reduced to a marginal thickened area. Prothoracic spiracle reduced. Dorsal abdominal spines absent.

Adult. Head: Occipital process absent; palpus with one globular segment; 19-20 cylindrical flagellomeres with anastomosing circumfila in both sexes. Basal flagellomeres slightly longer than distal ones. Flagellomere necks bare. 
Thorax. Wing: $\mathrm{R} 5$ longer than wing and bent downward, joining $\mathrm{C}$ beyond wing apex; Rs not conspicuous; $\mathrm{M} 3$ evanescent; $\mathrm{Cu}$ forked; $\mathrm{CuP}$ present. First tarsomeres without spur; tarsal claws toothed, bent beyond its midlength and longer than empodia; empodia well developed.

Abdomen. gonostylus short and ovoid with a subapical tooth; ovipositor short, barely protrusible; female cerci separate, splayed and setose.

Remarks. This genus is included among the Lasiopteridi by the number of flagellomeres and the presence of parameres that clasp the aedeagus. It belongs to the Oligotrophini, because of the long R5 vein. Mayteniella gen. n. will key to Haplopalpus Rübsaamen, 1916 in couplet 35 of GAGNÉ (1994). Both genera differ in the number of flagellomeres (19-20 in Mayteniella, 24 in Haplopalpus); the kind of ovipositor (protrusible in Mayteniella, nonprotrusible in Haplopalpus) and the shape of the pupal antennal horns (as a thickened area in Mayteniella, as elaborate horns in Haplopalpus).

Type species: Mayteniella distincta $\mathbf{s p .} \mathbf{n}$.

Etymology. Mayteniella refers to the generic name of the host plant species.

\section{Mayteniella distincta sp. $\mathbf{n}$.}

Figs $89-96$

Larva (Fig. 89). Body length: 1.1-1.4 mm. Colour: yellow with brown transversal bands. Spatula 2-toothed, length: $0.18-0.31 \mathrm{~mm}$, apical tooth pointed and stalk very reduced (Fig. 90). Papillae not visible.

Pupa. Body length: $2.5 \mathrm{~mm}$. Cephalic region (Fig. 91): antennal horn reduced; facial papillae absent; cephalic upper margin thickened laterally. Prothoracic spiracle setiform (length: $0.3 \mathrm{~mm}$ ). Wing sheath reaching the basal limit of the abdominal segment 3 . Fore, mid and hind legs sheath reaching the basal $1 / 3$ of the abdominal segment $6,1 / 2$ of the same segment and the distal $1 / 3$ of this segment, respectively. Abdominal tergites 2-8 with numerous spinules.

Adult. Head: Eyes facets circular. Flagellomeres necks bare and longer in female; circumfila linear in both sexes (Figs 92-93). Frontoclypeus with 38-40 long setae. Labrum triangular, long-attenuate, with three pairs of ventral sensory setae and long, anteriorly directed lateral setulae. Hypopharynx of the same shape as labrum with long, anteriorly directed, lateral setulae. Labella elongate-convex, each with several long lateral setae and two short mesal sensory setae. Palpus with one setose segment.

Thorax. Wings (Fig. 94): length: 2.6-2.8 mm. Anepisternum with a few scales near middle. Anepimeron with vertical row of several setae. Tarsal claws thin, bent beyond its midlength, toothed on all legs. Empodia reaching to bend in claws.

Abdomen. Tergites 1-6 rectangular with double, complete row of caudal setae, several lateral setae, two basal trichoid sensilla, and elsewhere with scattered scales. Tergite 7 with two basal trichoid sensilla. Tergite 8 (male) strap-like with only a basal trichoid sensilla for vestiture. Sternites 2-7 rectangular and setose, setae more abundant basally and mesally. Sternite 8 quadrate with caudal and midlength 


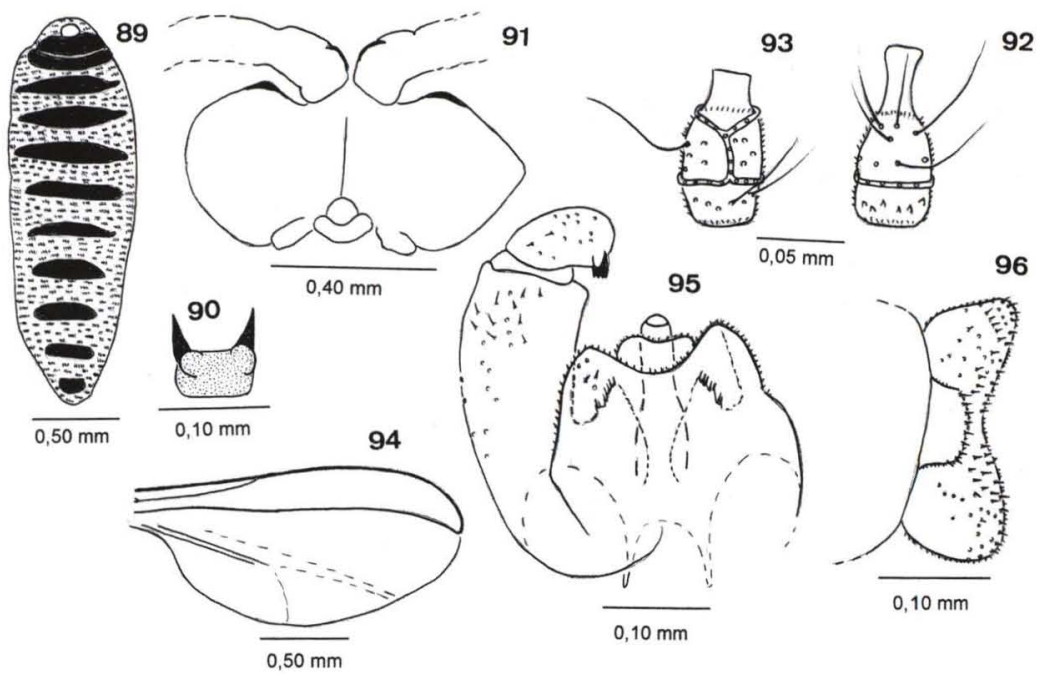

Figs 89-96. Mayteniella distincta sp. n. (89) Larva, general aspect (dorsal); (90) spatula (ventral); (91) pupa, cephalic region (ventral); (92) male, flagellomere $\mathrm{V}$; (93) female, flagellomere V; (94) male, wing; (95) male terminalia, dorsal; (96) female, cerci and hypoproct (ventral).

rows of setae and basal pair of trichoid sensilla. Female: tergites 1-8 as 1-6 in male, sternites 2-7 as 2-7 in male, tergite 8 unsclerotized, with a row of caudal setae, some lateral setae present and basal pair of trichoid sensilla. Sternite 9 with scattered setae. Male terminalia (Fig. 95): gonocoxite not splayed, gonostylus of uniform width; cercus wide and triangular; hypoproct sligthly bilobed; parameres short and setose; aedeagus and cercus subequal in length. Ovipositor barely protrusible, female cerci ovoid (Fig. 96).

Material. Holotype male. BraziL, Rio de Janeiro: Maricá (Itaipuaçu), 02.X.1998, V. Maia leg., MNRJ. Paratypes: same locality and collector - 1 male, 20.XII.1986; 2 males, 02.X.1998; 1 female 02.X.1998 (emerg.: 03.X.1998); 2 females, 02.X.1998; (emerg.: 08.X.1998); 1 female, 05.X.1998; 2 pupal exuviae, 02.X.1998, MNRJ. Paratypes - BRAZIL, Rio de Janeiro: Maricá (Barra de Maricá), same collector - 3 pupal exuviae, 17.VI.1997; 4 larvae, 20.VII.1995, MNRJ.

Gall. Circular leaf gall, projected on both surfaces (diameter: $0.6-0.7 \mathrm{~cm}$ ), glabrous, monothalamous, green or yellow and remarkable due to its hard walls. Host Plant: Maytenus obtusifolia Mart. var. obovata Mart. (Celastraceae).

Etymology. The name distincta refers to the remarkable hardness of the gall.

\section{Parazalepidota gen. $\mathbf{n}$.}

Larva. Cylindrical shaped and of regular width. Spatula with four teeth (two well developed and two very short). Sternal papillae with seta. Two pairs of setose lateral papillae per side, each with a very short seta. (Terminal segment in bad conditions).

Pupa. Lower and lateral papillae absent. Antennal horn well developed and 
with the margin micro serrated. Prothoracic spiracle reduced. Abdominal segments 2-8 with dorsal spines. Pupa pupates in gall.

Adult. Head: Occipital process absent; palpus with three setose segments; cylindrical flagellomeres in both sexes, except flagellomere 12 which is globular. Female $9^{\text {th }}-12^{\text {th }}$ flagellomeres progressively and conspicuously shortened; female circumfila straight; both sexes with anastomosing circumfila. Flagellomere necks short and bare.

Thorax. Wing: R5 straight, joining $\mathrm{C}$ before wing apex; Rs absent; M3 evanescent; $\mathrm{Cu}$ forked; $\mathrm{CuP}$ absent. First tarsomeres with a short spur; tarsal claws simple, stout and bent beyond its midlength; empodia shorter than claws. Claws similar on all legs.

Abdomen. Ovipositor protrusible, needlelike and striated. Cerci like lobes present just posterior to female eigth abdominal tergite. Teeth of gonostyli partly denticulate. Paramere present. Aedeagus narrow.

Remarks. This genus belongs to the tribe Asphondyliini by the number and shape of the flagellomeres, the short gonostylus and female sternite 7 much longer than the preceding sternites. The following characters place it in the subtribe Asphondyliina: reduced palpus, presence of an apical spur on the first tarsomeres and a bilobed structure at the posterior end of female tergite 8 , a needlelike ovipositor, gonostylus denticles fused, antennal horns well developed and dorsal spines on the abdominal segments 3-8. Parazalepidota gen. n. will key to Zalepidota Rübsaamen, 1907 in couplet 5 of GAGNÉ (1994), but the new genus does not have a dense network of circumfila, nor the ventral lobes on antennal horns or elongated spiracles on the abdominal segments 1-7, all characters present in Zalepidota. Besides, both genera differ in the shape of the pupal antennal horn and in the number of lobes at the base of the ovipositor (one in Zalepidota and two in Parazalepidota gen. n.). The new genus contains a single species reared from Clusia fluminensis (Clusiaceae).

Type species: Parazalepidota clusiae sp. $\mathbf{n}$.

Etymology. The generic name is composed of para (a latin prefix that means similar) + Zalepidota.

\section{Parazalepidota clusiae sp. $\mathbf{n}$.}

Figs $97-105$

Larva. Body length: $1.2 \mathrm{~mm}$. Color: yellow. Spatula 4-toothed, length: 0.25 $\mathrm{mm}$, inner tooth longer than outer ones; stalk developed (Fig. 97). Sternal papillae setose. Two pairs of setose lateral papillae (Fig. 97).

Pupa. Length (from antennal to distal margin of wing sheath): $1.5-1.6 \mathrm{~mm}$. Cephalic region (Fig. 98): antennal horn well developed, triangular and with 0.15-0.17 $\mathrm{mm}$ of length; lower and lateral papillae absent; upper cephalic margin thickened laterally; cephalic seta with $0.06-0.07 \mathrm{~mm}$ of length. Prothoracic spiracle setiform and short (length: $0.05 \mathrm{~mm}$ ). Specimens with distorted abdomen. Abdominal tergites II-VIII with abundant dorsal spines, the proximal ones shorter than the distal spines. 


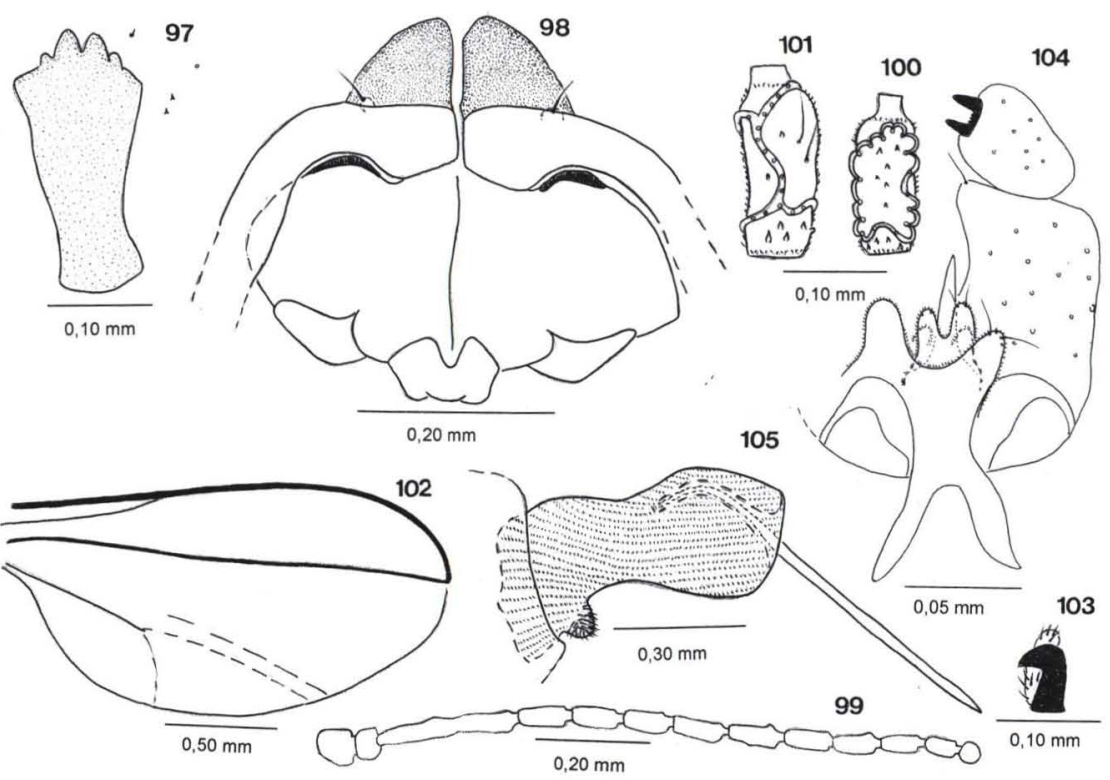

Figs 97-105. Parazalepidota clusiae sp. n. (97) Larva, spatula, sternal and lateral papillae (ventral); (98) pupa, cephalic region (ventral); (99) female, antenna; (100) male, flagellomere V; (101) female, flagellomere V; (102) male, wing; (103) tarsal claw and empodium; (104) male terminalia, dorsal; (105) female terminalia (lateral).

Adult. Head: Eyes facets circular, closely approximated. Antenna with scape 1.6 times longer than pedicel; pedicel about as wide as long. Flagellomeres cylindrical in both sexes, bare necks and anastomosing circumfila. First flagellomere about two times longer than scape; proportions of female segments and flagellomeres as in figure 99. Last flagellomere globular in female and cylindrical in male; male and female circumfila straight (Figs 100,101). Frons with 10-14 setae. Clypeus asetose dorsally, with several short setae laterally, and setulose ventrally. Hypopharynx closely lined with setulae dorsoapically. Labella setose and setulose laterally and ventrally (with small area of setulae and 1-2 setae mesally). Palpus with two or three segments, if two: first segment claviform, wider apically, twice as long as the second segment; second conical, about twice as long as wide; if three: first segment globular, second claviform, about twice as long as apical wide (length: $0.08 \mathrm{~mm}$ ); third cylindrical, narrower than the second, about three times as long as medial wide (length: $0.05 \mathrm{~mm}$ ), all covered with setulae and setae.

Thorax. Wing as in figure 102. Wings length, male: $1.0-2.0 \mathrm{~mm}(\mathrm{n}=4)$, female, 2.1-2.4 $(n=4)$. Dorsal setal row at midlength with two rows of setae intermixed with scales, the row continuing onto scutellum to posterior margin. Scutellum bare between dorsocentral rows of setae, with setae posteriorly laterad of dorsocentral rows, and otherwise with sparse scales laterally. Anepisternum with 
setae and scales on dorsal half. Anepimeron covered with setae. Katepimeron bare. Tarsal claws simple (thin in male, stout in female), all equal in size and shape, longer than empodia. First tarsomeres with a spur. Empodia well developed (Fig. 103).

Abdomen. Tergites 1-7 rectangular with 1-3 irregular rows of setae at distal margin. Tergite 8 (male) linear and with one trichoid sensilla. Sternites 1-5 rectangular with setae, more abundant basally and mesally; sternites 6-7 rectangular with setae, except in the distal 1/4. Tergites without anterior pair of trichoid sensilla, first through seventh tergites rectangular with mostly single row of posterior setae (sparser in male than in female), mostly double row on seventh tergite, several lateral setae, elsewhere covered with scales, width of sixth and seventh tergites about three times length; eighth tergite short, bandlike, without vestiture. Sternites without anterior pair of trichoid sensilla, width sixth sternite about twice length, male eigth sternite reduced in size, wider than long. Male terminalia (Fig. 104): gonocoxites not splayed and tapering to the apex, gonostylus ovoid; teeth of gonostyli partly denticulate; cercus triangular; hypoproct deeply bilobed; parameres short; aedeagus elongate and tapering to apex. Ovipositor protrusible and needlelike (Fig. 105).

Material. Holotype male. BraziL, Rio de Janeiro: Maricá (Barra de Maricá), 05.X.1998 (emerg.: 12.X.1998), V. Maia leg., MNRJ. Paratypes: same locality, date and collector - 1 male (emerg.: 12.X.1998), 2 females (emerg.: 12.X.1998 and 13.X.1998), 1 larva, MNRJ. Paratypes - BRAzIL, Rio de Janeiro: Niterói (Forte Barão do Rio Branco), same collector: 7 females, 14.VIII.1997, 6 pupal exuviae, 17.VIII.1998.

Gall. Circular leaf gall (diameter: $0.5 \mathrm{~cm}$ ), glabrous, monothalamous and green. Host plant: Clusia fluminensis Tr. \& Pl. (Clusiaceae).

Etymology. The name clusiae is the genitive of the host plant name.

\section{Paulliniamyia gen. $\mathbf{n}$.}

Larva. Cylindrical shaped and of regular width. Spatula with two pointed teeth, the stalk strongly reduced. Sternal papillae nonsetose. Two lateral papillae with a very short seta per side. Two pairs of setose terminal papillae.

Pupa. Lower and lateral papillae absent. Antennal horn well developed, elongate, triangular and with margin micro serrated; abdominal spines absent. Upper cephalic margin thickened laterally. Prothoracic spiracle reduced. Abdominal segments $2-8$ with spinules.

Adult. Head: Occipital process absent; palpus with three setose segments; antenna: 18-21 cylindrical flagellomeres and circumfila as two undulate horizontal rings in both sexes; flagellomere necks bare.

Thorax. Wing: R5 straight, joining $\mathrm{C}$ just behind wing apex; Rs present; M3 evanescent; $\mathrm{Cu}$ forked; $\mathrm{CuP}$ present. First tarsomeres without spur; tarsal claws toothed and bent beyond its midlength; empodia reaching claws curvature.

Abdomen. Gonocoxites wide and not splayed, gonostylus stout and wider to the apex, cercus rounded and hypropoct bilobed and setose; parameres well developed. Ovipositor protrusible, female cercus fused, elongate and rounded apically. 
Remarks. This genus belongs to Oligotrophini (Lasiopteridi), but it will not run past couplet 38 in GAGNÉ (1994), because it has a three-segmented palpus. This couplet leads to Scheureria and Rhopalomyia, whose palpus has one and two segments, respectively.

Type species: Paulliniamyia ampla $\mathbf{s p .} \mathbf{n}$.

Etymology.Paulliniamyia refers to the generic name of the host plant species + myia.

\section{Paulliniamyia ampla sp. $\mathbf{n}$. \\ Figs 106-113}

Larva. Body length: 2.3-2.6 mm. Color: yellow. Spatula 2-toothed (teeth elongate and narrow); length: $0.13-0.17 \mathrm{~mm}$; stalk reduced (Fig. 106). Sternal papillae without seta and two setose lateral papillae per side. Terminal segment with two pairs of papillae (one larger than the other) (Fig. 107).

Pupa. Length: 2.8-4.8 mm. Cephalic region: antennal horn (Fig. 108) measuring $0.15-0.19 \mathrm{~mm}$; cephalic papillae with the full complement; cephalic seta short (length: 0.07-0.09 $\mathrm{mm}$ ); lower and lateral papillae absent; upper cephalic margin thickened laterally. Prothoracic spiracle setiform and reduced (length: $0.06 \mathrm{~mm}$ ). Wing sheath reaching medial $1 / 3$ of the abdominal segment 3 ; fore, mid and hind leg sheaths reaching $1 / 2$ of the terminal segment, the distal margin of the same segment and overtaking the terminal segment. Abdominal tergites 2-8 with spinules.

Adult. Head: Occipital process absent. Eyes facets hexagonal; male and female flagellomeres cylindrical, with two horizontal rings undulate and necks bare (Figs 109-1 10). Frontoclypeus with 38-40 long setae. Labrum triangular, long-attenuate, with three pairs of ventral sensory setae and long, anteriorly directed lateral setulae. Hypopharynx of the same shape as labrum with long, anteriorly directed, lateral setulae. Labella elongate-convex, each with several long lateral setae and two short mesal sensory setae. Palpus with three setose and crescent segments: the first globular, the second and third cylindrical, the second the widest one.

Thorax. Wing (Fig. 111): length: 1.8-3.4 mm. Anepisternum with a few scales near middle. Anepimeron with many mesal setae. Tarsal claws bent beyond its midlength, toothed on all legs. Empodia reaching to bend in claws.

Abdomen. Tergites 1-6 rectangular with double, complete row of caudal setae, several lateral setae, two basal trichoid sensilla, and elsewhere with scattered scales. Tergite 7 rectangular, unsclerotized, with few lateral setae and two basal trichoid sensilla. Tergite 8 (male) unsclerotized rectangular with only basal trichoid sensilla for vestiture. Sternites 2-7 rectangular and setose, setae more abundant basally and mesally. Sternite 8 quadrate with caudal and midlength rows of setae and basal pair of trichoid sensilla. Female: tergites 1-7 as for 1-6 in male, sternites 2-7 as for 2-8 of male, tergite 8 unsclerotized, with a row of short caudal setae and basal pair of trichoid sensilla and short. Sternite 9 with scattered setae. Male terminalia (Fig. 112): gonocoxites wide and not splayed; gonostylus wider basally and gradually tapering to apex and slightly bent; cercus wide and rounded; hypoproct narrow, slightly longer than cercus and with lobes parallel; parameres longer 


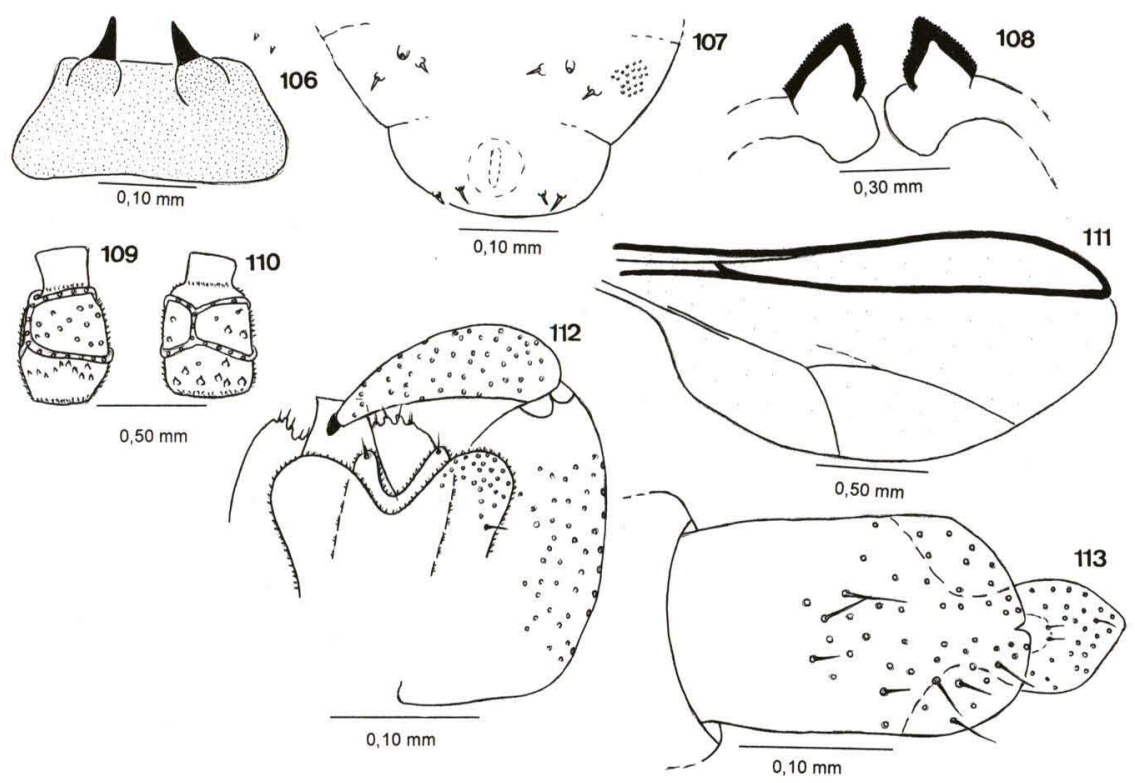

Figs 106-113. Paulliniamyia ampla sp. n. (106) Larva, spatula, sternal and lateral papillae (ventral); (107) larval posterior segments (ventral); (108) pupa, antennal horn; (109) male, flagellomere $V_{;}(110)$ female, flagellomere $V_{;}(111)$ male, wing; (112) male terminalia, dorsal; (113) female terminalia (dorsal).

than cercus; aedeagus wide, discretely longer than parameres, tapering gradually to apex and straight apically. Ovipositor protrusible, female cerci fused and setose (Fig. 113).

Material. Holotype male. BRAZIL, Rio de Janeiro: Arraial do Cabo,.X.1987, V. Maia leg., MNRJ. Paratypes: same locality, date and collector -3 males and 2 females, MNRJ. Paratypes: same locality and collector: 2 females, X.1988; 1 pupal exuviae, 24.X.1987; 1 pupal exuviae, VIII.1988, MNRJ. Paratypes - BRAZIL, Rio de Janeiro: Maricá (Barra de Maricá), same colllector: 1 male, 24.X.1988; 1 female, 17.VII.1992; 3 pupal exuviae, 24.X.1987; 1 pupal exuviae, 17.VII.1992; 1 pupal exuviae, II.1998; 1 larva, 17.VII.1992, MNRJ. Paratypes - BRAZIL, Rio de Janeiro: Carapebus, same collector: 6 larvae, 29.VI.1998, MNRJ.

Gall. Conical leaf; length: $0.6 \mathrm{~cm}$; width: $0.2 \mathrm{~cm}$; glabrous; monothalamous; green or yellow. Host Plant: Paullinia weinmanniaefolia Mart. (Sapindaceae). Etymology. The name ampla refers to the large adult body.

ACKNOWLEDEGMENTS. I wish to thank Dr. Raymond J. Gagné (Systematic Entomology Laboratory, USDA, USA) and Dr. Márcia Couri for the manuscript review; to CAPES (Fundação de Coordenação de Aperfeiçoamento de Pessoal de Nível Superior) and FAPERJ (Fundação de Amparo à Pesquisa do Estado do Rio de Janeiro, Proc. E-26/151.714/1999) for financial support from 1996 until 1999 and from 2000, respectively. 


\section{REFERENCES}

Couri, M.S. \& V.C. MaIA. 1992. Considerações sobre Pisphondylia Möhn, 1960 (Diptera, Cecidomyiidae, Asphondyliidi), com descrição de uma espécie nova do Brasil. Revta bras. Ent. 36 (4): 729-730.

Gagnt, R.J. 1989. The Plant-Feeding Gall Midges of North America. Ithaca, Cornell Univ. Press, $356 \mathrm{p}$.

— 1994. The Gall Midges of the Neotropical Region. Ithaca, Cornell Univ. Press, 352p.

MAIA, V.C. 1993a. Descrição de duas espécies novas de Cecidomyiidae (Diptera) associadas a Eugenia spp. (Myrtaceae). Revta bras. Ent. 37 (4): 717-721.

—.1993b. Considerações sobre Proasphondylia Felt (Diptera, Cecidomyiidae) com descrições de duas espécies novas associadas com Guapira opposita (Velloso) Reitz (Nyctaginaceae). Revta bras. Zool. 10 (2): 215-218.

1993c. Considerações sobre Stephomyia Tavares (Diptera, Cecidomyiidae, Asphondyliidi), com descrição de quatro espécies novas associadas com Eugenia L. e Neomitranthes obscura (DC.) Legr. (Myrtaceae). Revta bras. Zool. 10 (3): 521-530.

- 1994. Myrciariamyia bivalva, gen. n. e sp. n. (Diptera, Cecidomyiidae, Oligotrophini) associado com Myrciaria floribunda (Camb.) Legr. (Myrtaceae) no Brasil. Revta bras. Zool. 11 (4): 635-639.

. 1995a. Dois gêneros novos de Cecidomyiidae (Diptera) associados a Myrtaceae na Restinga de Barra de Maricá, Rio de Janeiro, Brasil. Revta bras. Zool. 12 (3): 567-574.

- 1995b. Três espécies novas de Dasineura Rondani, 1840 (Diptera, Cecidomyiidae) associadas a Myrtaceae na Restinga de Barra de Maricá, Rio de Janeiro. Revta bras. Zool. 12 (4): 1001-1008.

- 1995c. Chaves para classificação de galhas de Cecidomyiidae (Diptera) em Myrtaceae na Restinga da Barra de Maricá, Rio de Janeiro. Revta bras. Zool. 12 (4): 1009-1013.

- 1996a. Cordiamyia globosa gen. n. e sp. n. (Diptera, Cecidomyiidae, Cecidomyiidi) associado com Cordia verbenacea DC. (Boraginaceae) no Brasil. Revta bras. Zool. 13 (3): 579-583.

- 1996b. Clusiamyia nitida gen. n. e sp. n. (Diptera, Cecidomyiidae, Cecidomyiidi) associada com Clusia lanceolata Camb. (Clusiaceae) no Brasil. Revta bras. Zool. 13 (4): 829-832.

-1999a. Description of male, pupa and larva of Neolasioptera cerei Rübsaamen (Diptera, Cecidomyiidae). Revta bras. Zool. 16 (2): 119-122.

-1999b. Descrição de imaturos de quatro espécies de Asphondyliini neotropicais e nota taxomômica sobre Asphondylia maytenuse Maia \& Couri (Diptera, Cecidomyiidae). Revta bras. Zool. 16 (3): 775-778.

-1999c. Artrópodes associados às galhas de Cecidomyiidae (Diptera) em Eugenia rotundifolia (Myrtaceae) e Clusia lanceolata (Clusiaceae) em uma restinga do Estado do Rio de Janeiro. Iheringia, Sér. Zool., 87: 75-79.

- (in press). The gall midges (Diptera, Cecidomyiidae) from three restingas of Rio de Janeiro State (Brazil). Revta bras. Zool.

MaIA, V.C. \& M.S. Couri. 1993. Descrição de três espécies novas de Bruggmannia Tavares, 1906 (Diptera, Cecidomyiidae, Asphondyliidi) do Brasil associadas com Guapira opposita (Nyctaginaceae). Rev. Brasil. Biol. 53 (2): 209-215.

Maia, V.C.; M.S. Couri \& R.F. Monteiro. 1992. Sobre seis espécies de Asphondylia Loew, 1850 do Brasil (Diptera, Cecidomyiidae). Revta bras. Ent. 36 (3): 653-661.

MaiA, V.C. \& R.F. Monteiro. 1999. Espécies cecidógenas (Diptera, Cecidomyidae) e parasitóides (Hymenoptera) associados a Guapira opposita (Vell.) Reitz (Nyctaginaceae) na Restinga da Barra de Maricá, Rio de Janeiro. Revta bras. Zool. 16 (2): 483-487.

MCAlPINE, J.F. 1981. Manual of Neartic Diptera. Quebec, Research Branch Agriculture Canada, Vol. $1,674 \mathrm{p}$.

Monteiro, R.F.; F. Ferra7; V.C. MaiA \& M.A.P. A7evf.do. 1993. Galhas entomógenas em restingas: uma abordagem preliminar. An. III Simp. Ecossist. Costa Brasileira, ACIESP 87, p. $210-220$.

Recebido em 10.VIII.2000; aceito em 30.V.2001. 